\title{
Jatrorrhizine: A Review of Sources, Pharmacology, Pharmacokinetics and Toxicity
}

\author{
Furong Zhong ${ }^{1,2}$, Yang Chen ${ }^{1,2}$, Jia Chen ${ }^{1,2}$, Hailang Liao ${ }^{1,2}$, Yirou $\mathrm{Li}^{1,2}$ and Yuntong $\mathrm{Ma}^{1,2 *}$ \\ ${ }^{1}$ State Key Laboratory of Characteristic Chinese Medicine Resources in Southwest China, Chengdu University of Traditional \\ Chinese Medicine, Chengdu, China, ${ }^{2}$ School of Pharmacy, Chengdu University of Traditional Chinese Medicine, Chengdu, China
}

\section{OPEN ACCESS}

Edited by:

Michael Heinrich,

UCL School of Pharmacy,

United Kingdom

Reviewed by:

Guozheng Huang,

Anhui University of Technology, China Juan Carlos Sepúlveda-Arias,

Technological University of Pereira,

Colombia

*Correspondence:

Yuntong Ma

Mayuntong@cdutcm.edu.cn

Specialty section:

This article was submitted to

Ethnopharmacology,

a section of the journal

Frontiers in Pharmacology

Received: 29 September 2021

Accepted: 14 December 2021

Published: 13 January 2022

Citation:

Zhong F, Chen Y, Chen J, Liao H, Li Y and Ma $Y$ (2022) Jatrorrhizine: $A$ Review of Sources, Pharmacology,

Pharmacokinetics and Toxicity.

Front. Pharmacol. 12:783127.

doi: 10.3389/fphar.2021.783127
Jatrorrhizine, an isoquinoline alkaloid, is a bioactive metabolite in common medicinal plants, such as Berberis vernae Schneid., Tinospora sagittata (Oliv.) Gagnep. and Coptis chinensis Franch. These plants have been used for centuries in traditional medicine for their wide-ranging pharmacological properties. This review emphasizes the latest and comprehensive information on the sources, pharmacology, pharmacokinetics and toxicity of jatrorrhizine. Studies on this alkaloid were collected from scientific internet databases, including the Web of Science, PubMed, ScienceDirect, Google Scholar, Elsevier, Springer, Wiley Online Library and Europe PMC and CNKI, using a combination of keywords involving "jatrorrhizine", "sources", "pharmacology," "pharmacokinetics," and "toxicology". Jatrorrhizine exhibits anti-diabetic, antimicrobial, antiprotozoal, anticancer, anti-obesity and hypolipidemic properties, along with central nervous system activities and other beneficial activity. Studies of jatrorrhizine have laid the foundation for its application to the treatment of various diseases, but some issues still exist. Further investigations might emphasize 1) specific curative mechanisms of

Abbreviations: 3OHase, tyrosine/tyramine 3-hydroxylase; 4-HNE, 4-hydroxynonenal; 4HPPDC, 4-hydroxyphenylpuruvate decarboxylase; 4'OMT, 3'-hydroxy-N-methyl-(S)-coclaurine 4'-O-methyltransferase; 53BP1, p53-binding protein 1; 5-HT, serotonin; 6OMT, (S)-norcoclaurine 6-O-methyltransferase; $A \beta$, amyloid $\beta$; $A C h E$, acetylcholinesterase; Apaf-1, apoptotic protease activating factor 1; ALT, alanine aminotransferase; AR, aldose reductase; AST, aspartate transaminase; Bax, BCL-2associated X protein; BBE, berberine bridge enzyme; Bcl-2, B cell lymphoma 2; BMD, bone mineral density; BV/TV, bone volume/tissue volume; CDK, cyclin-dependent kinase; CNMT, (S)-coclaurine $\mathrm{N}$-methyltransferase; CPT1A, carnitine palmitoyltransferase 1A; CODM, codeine-O-demethylase; CTR, calcitonin receptor; CTSK, cathepsin K; CYP7A1, cholesterol 7ahydroxylase; eNOS, endothelial nitric oxide synthase; EMT, epithelial-mesenchymal transition; ERCC1, excision repair crosscomplementation group 1; FAS, fatty acid synthase; GLUT4/1/2, glucose transporter 4/1/2; GSH, glutathione; GSK-3 $\beta$, glycogen synthase kinase-3 $\beta$; HDAC4, histone deacetylase 4; HDL-C, high-density lipoprotein cholesterol; HMGCR, 3-hydroxy-3methyl glutaryl coenzyme A reductase; HO-1, heme oxygenase-1; hTERT, human telomerase reverse transcriptase; IDO-1, indoleamine 2, 3-dioxygenase 1; IL-1 $\beta$, interleukin-1 $\beta$; IRS2, insulin receptor substrate 2; LDH, lactate dehydrogenase; LDL-C, low-density lipoprotein cholesterol; LDLR, low density lipoprotein receptor; MAO, monoamine oxidase; MAPK, mitogenactivated protein kinases; MDA, lipid peroxidation; MIC, minimum inhibitory concentration; MMP $(\triangle \Psi \mathrm{m})$, mitochondrial membrane potential; NA, neuraminidase; NCS, (S)-norcoclaurine synthase; NE, norepinephrine; NFATc1, T-cells cytoplasmic 1; NF-kB, nuclear factor kappa-B; NMCH, (S)-N-methylcoclaurine-3'-hydroxylase; OCT, organic cation transporter; OMT, O-methyltransferase; $\mathrm{p}-4 \mathrm{E}-\mathrm{BP} 1$, phosphorylated 4E-binding protein 1; PARP, ADP-ribose polymerase; $\mathrm{p}$-AKT, phosphorylated protein kinase B; p-AMPK, phospho-AMP-activated protein kinase; p-ERK1/2, phosphorylated extracellular signalregulated kinases 1/2; pH2AX, phosphorylated $\mathrm{H} 2 \mathrm{~A}$ histone $\mathrm{X}$; PI3KR1, phosphoinositide-3-kinase regulatory subunit 1; p-JNK, phosphorylated c-Jun N-terminal kinases; PMAT, plasma membrane monoamine transporter; PPAR, peroxisome proliferator activated receptor; $\mathrm{p}-\mathrm{p} 38$, phosphorylated p38; ROS, oxygen species; SOMT, (S)-scoulerine 9-O-methyltransferase; SREBP-1c, sterol regulatory element binding transcription factor 1c; STOX, (S)-tetrahydroprotoberberine oxidase; T2DM, type 2 diabetes mellitus; TBA, total bile acids; TC, total cholesterol; TRF1, TTAGGG repeat binding factor 1; TG, total triglyceride; TNF- $\alpha$, tumor necrosis factor $\alpha$ TRAP, tartrate-resistant acid phosphatase; TYDC, tyrosine decarboxylase; TyrAT, tyrosine aminotransferase. 
jatrorrhizine and clinical utility, 2) application prospect in the treatment of metabolic disorders, 3) comprehensive investigations of the toxicity mechanisms and 4) interactions of jatrorrhizine with other pharmaceuticals and development of derivatives.

Keywords: jatrorrhizine, natural products, pharmacological properties, toxicology, pharmacokinetics

\section{INTRODUCTION}

Plants are sources of metabolites with varied biological activities, clinical effectiveness. The therapeutical benefits and safety of plant-derived metabolites have been proven in long-standing traditional medicinal practices across the world (Gurib-Fakim, 2006; Porras et al., 2020). The bioactive metabolites and related derivatives are increasingly used for the production of new drugs and may have broad clinical applications.

Alkaloids are important natural products derived mostly from amino acids. These chemicals display substantial physiological and pharmacological activities. Jatrorrhizine is a well-known isoquinoline alkaloid of the protoberberine type. Its molecular structure is 2,9,10-trimethoxy-5,6-dihydroisoquinolino[2,1-b] isoquinolin-7-ium-3-ol (molecular formula: $\mathrm{C}_{20} \mathrm{H}_{20} \mathrm{NO}_{4}$, Figure 1). Jatrorrhizine is a major bioactive metabolite with wide distribution across plant families. Several species have been used medicinally for centuries, such as Berberis vernae C.K.Schneid. (Li et al., 2020), Mahonia bealei (Fortune) Carrière ( $\mathrm{He}$ and $\mathrm{Mu}, 2015)$, Tinospora sagittata (Oliv.) Gagnep. (Zhang et al., 2006), Coptis chinensis Franch. (Chen et al., 2017) and Corydalis yanhusuo (Y.H.Chou and Chun C. Hsu) W.T.Wang ex Z.Y.Su and C.Y.Wu (Xiao et al., 2011). One of the active constituents in herbal formulae, such as Zoujinwan, Jiaotai Pills and San-Huang decoction, is considered to be jatrorrhizine (Yan et al., 2012; Sun et al., 2018; Su et al., 2020). Modern pharmacological studies demonstrate that this alkaloid exhibits anti-diabetic, antimicrobial (Ali et al., 2013), antiprotozoal (Malebo et al., 2013), anticancer (Sun et al., 2019), anti-obesity and hypolipidemic properties (Yang et al., 2016). Central nervous system activities are also reported (Luo et al., 2011; Xiao et al., 2011; Bacq et al., 2012).

Jatrorrhizine has attracted the attention of researchers due to its wide distribution across a variety of plant species and its potential for clinical use certain diseases. We summarise and

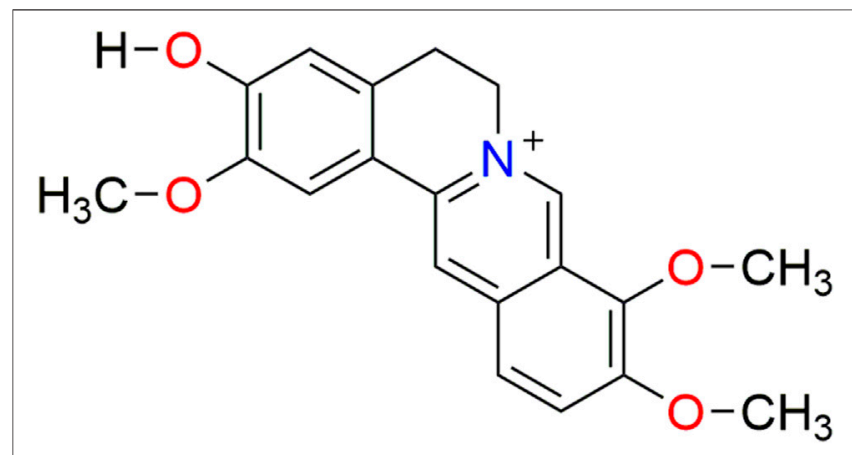

FIGURE 1 | The chemical structure of jatrorrhizine. discuss, in this review, the latest and comprehensive information on the plant sources, synthesis, pharmacological effects, pharmacokinetics and toxicity of jatrorrhizine. This information will be beneficial for future examination of therapeutic potential of this active metabolite and subsequent development of clinical applications.

\section{SOURCES}

\section{Plant Sources of Jatrorrhizine}

Medicinal plants are major sources of jatrorrhizine. This metabolite is isolated from various plant families, such as Annonaceae, Berberidaceae, Menispermaceae, Papaveraceae, Ranunculaceae and Rutaceae (Table 1). Many species in these families are used in folk medicinal plants and Chinese herbal medicine. Several Annickia species from the Annonaceae family, are multi-purpose medicinal plants used widely for the treatment of malaria and other ailments across tropical Africa. Protoberberine alkaloids (including jatrorrhizine and palmatine) are the major anti-protozoal agents in these plants (Malebo et al., 2013; Olivier et al., 2015; Odoh et al., 2018). Numerous species of the Berberis, Mahonia, Tinospora, Corydalis, Coptis, Thalictrum and Phellodendron genera are commonly used medicinal plants and important sources of jatrorrhizine (Alamzeb et al., 2015; Bajpai et al., 2016; Du et al., 2018; Feng et al., 2018; Abdykerimova et al., 2020; Sharma et al., 2020). In China, the stems of Mahonia bealei (Fortune) Carrière and Mahonia fortunei (Lindl.) Fedde (named Mahoniae Caulis), rhizomes of Coptis chinensis Franch., Coptis deltoidea C.Y.Cheng and P.K.Hsiao and Coptis teeta Wall. (named Coptidis Rhizoma) and barks from Phellodendron amurense Rupr. (named Phellodendri amurensis Cortex) and Phellodendron chinense C.K.Schneid. (named Phellodendri Chinensis Cortex) are known for antipyretic and analgesic properties. These traditional medicines have been widely used to treat abdominal pain and diarrhea, inflammatory disorders and gastrointestinal diseases (Ryuk et al., 2012; He and Mu, 2015; Meng et al., 2018). However, the wild resources of the three Coptis species are almost endangered (Chen et al., 2017). Jatrorrhizine is also found in the Rutaceae stem barks of several Zanthoxylum species. The anti-cancer activity of these plants might be attributed to quaternary alkaloids (Tian et al., 2017).

\section{Synthesis of Jatrorrhizine}

Access to natural products with complex structures is a major challenge because of slow growth and limited production (Romanowski and Eustáquio, 2020). Chemical synthesis has thus become an effective way to obtain some plant metabolites. Total synthesis of jatrorrhizine has been achieved through an efficient 
TABLE 1 | The plant sources of jatrorrhizine.

\section{Plant species}

Annickia affinis (Exell) Versteegh and Sosef

Annickia chlorantha (Oliv.) Setten and Maas

Annickia kummeriae (Engl. and Diels) Setten and Maas

Duguetia trunciflora Maas and A.H.Gentry

Xylopia parviflora Spruce

Berberis aristata DC.

Berberis brevissima Jafri

Berberis dictyophylla Franch.

Berberis diaphana Maxim.

Berberis iliensis Popov

Berberis jaeschkeana C.K.Schneid.

Berberis kansuensis C.K.Schneid.

Berberis parkeriana C.K.Schneid.

Berberis vernae C.K.Schneid.

Mahonia aquifolium (Pursh) Nutt.

Mahonia bealei (Fortune) Carrière

Mahonia fortunei (Lindl.) Fedde

Mahonia leschenaultia (Wall. ex Wight and Arn.) Takeda ex Gamble

Mahonia napaulensis DC.

Mahonia oiwakensis Hayata

Nandina domestica Thunb.

Burasaia australis Elliot

Burasaia congesta Decne.

Burasaia gracilis Decne.

Dioscoreophyllum cumminsii (Stapf) Diels

Fibraurea recisa Pierre.

Fibraurea tinctoria Lour.

Penianthus zenkeri (Engl.) Diels

Sphenocentrum jollyanum Pierre

Stephania cambodica Gagnep.

Stephania rotunda Lour.

Stephania yunnanensis H.S. Lo

Tinospora capillipes Gagnep.

Tinospora cordifolia (Willd.) Hook.f. and Thomson

Tinospora sagittata (oliv.) Gagnep.

Corydalis decumbens (Thunb.) Pers.

Corydalis nobilis (L.) Pers.

Corydalis yanhusuo (Y.H.Chou and Chun C.Hsu) W.T.Wang ex Z.Y.Su and

C.Y.Wu

Eschscholzia californica Cham.

Aquilegia Formosa Fisch.

Coptis chinensis Franch.

Coptis deltoidea C.Y.Cheng and P.K.Hsiao

Coptis omeiensis (C.Chen) C.Y.Cheng

Coptis japonica (Thunb.) Makino

Coptis quinquefolia Miq.

Coptis quinquesecta W.T.Wang

Coptis teeta Wall.

Hydrastis canadensis L.

Thalictrum angustifolium L.

Thalictrum cultratum Wall.

Thalictrum foliolosum DC.

Thalictrum simplex L.

Thalictrum squarrosum Stephan ex Willd.

Phellodendron amurense Rupr.

Phellodendron chinense C.K.Schneid.

Zanthoxylum ailanthoides Siebold and Zucc.

Zanthoxylum chalybeum Engl.

Zanthoxylum simulans Hance
Family

Used part

References

Annonaceae

Annonaceae

Annonaceae

Annonaceae

stem bark

stem bark

leaf

Annonaceae

Berberidaceae

Berberidaceae

Berberidaceae

Berberidaceae

Berberidaceae

Berberidaceae

Berberidaceae

Berberidaceae

Berberidaceae

Berberidaceae

Berberidaceae

Berberidaceae

Berberidaceae

Berberidaceae

Berberidaceae

Berberidaceae

Menispermaceae

Menispermaceae

Menispermaceae

Menispermaceae

Menispermaceae

Menispermaceae

Menispermaceae

Menispermaceae

Menispermaceae

Menispermaceae

Menispermaceae

Menispermaceae

Menispermaceae

Menispermaceae

Papaveraceae

Papaveraceae

Papaveraceae

Papaveraceae

Ranunculaceae

Ranunculaceae

Ranunculaceae

Ranunculaceae

Ranunculaceae

Ranunculaceae

Ranunculaceae

Ranunculaceae

Ranunculaceae

Ranunculaceae

Ranunculaceae

Ranunculaceae

Ranunculaceae

Ranunculaceae

Rutaceae

Rutaceae

Rutaceae

Rutaceae

Rutaceae leaf

bark and root

root

cortex

cortex

cortex

root, leaf and fruit

bark of root

cortex

cortex

cortex

root

root, stem

root, root bark stem

root

root

root

fruit, ground parts

root

root

root

stem, leaf, tuber

stem bark

stem bark

leaf, root

root

tuber

stem, leaf, tuber

tuber

root

stem

stem

rhizome

rhizome

tuber

root

root

rhizome

rhizome

rhizome

rhizome

rhizome

rhizome

rhizome

root

root

root

root

root

root

stem bark

stem bark

stem bark

stem bark

stem bark
Olivier et al. (2015)

Odoh et al. (2018), Olivier et al. (2015)

Malebo et al. (2013)

Fechine et al. (2002), Pérez and Cassels

(2010)

Nishiyama et al. (2004)

Basera et al. (2021)

Ali et al. (2013)

Feng et al. (2018)

Feng et al. (2018)

Abdykerimova et al. (2020)

Alamzeb et al. (2015)

Feng et al. (2018)

Ali et al. (2013)

Feng et al. (2018)

Slobodníková et al. (2004)

$\mathrm{He}$ and $\mathrm{Mu}$ (2015)

$\mathrm{He}$ and Mu (2015)

Singh et al. (2017)

Singh et al. (2017)

Chao et al. (2009)

Iwasa et al. (2008), Peng et al. (2014)

Da-Cunha et al. (2005)

Da-Cunha et al. (2005)

Da-Cunha et al. (2005)

Furuya et al. (1983)

Su et al. (2007)

Rao et al. (2009)

Achenbach and Hemrich (1991)

Hussain et al. (1989)

Dary et al. (2017)

Zhang and Rao (2009)

Desgrouas et al. (2014)

Xiang et al. (2016);

Bajpai et al. (2016);

Yuan et al. (2010)

Mao et al. (2017)

Slavík and Slavíková (1989)

Du et al. (2018)

Kukula-Koch (2017)

Constantine et al. (1966)

He et al. (2014b);

He et al. (2014b)

He et al. (2014b)

Ikuta et al. (1975)

Da-Cunha et al. (2005)

Da-Cunha et al. (2005)

He et al. (2014b)

Le et al. (2014)

Alhowiriny et al. (2002)

Lou et al. (1987)

Sharma et al. (2020)

Qin and Jiang (2011)

Qin and Jiang (2011)

Ryuk et al. (2012)

Ryuk et al. (2012)

Tian et al. (2017)

Tian et al. (2017)

Tian et al. (2017) 


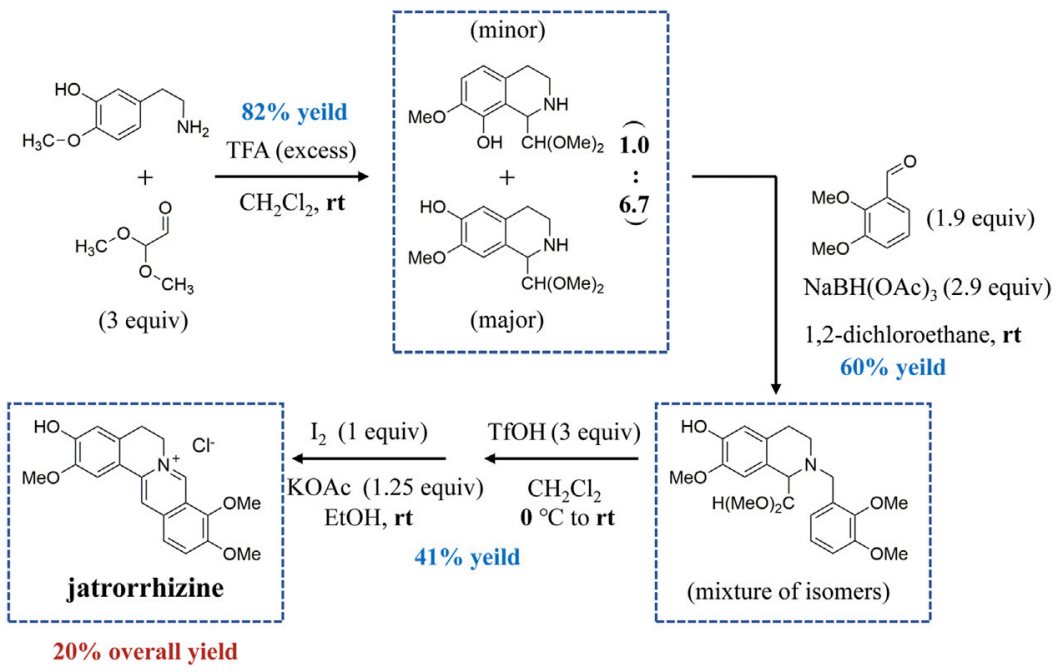

FIGURE 2 | The total syntheses of jatrorrhizine based on a unified strategy.

syntheses strategy in four steps (Figure 2). The alkaloid was synthesized from phenethylamine and 2,2-dimethoxyacetaldehyde using the Pictet-Spengler reaction to provide tetrahydroisoquinoline. This intermediate then reductively aminated with 2,3-dimethoxybenzaldehyde to afford the tertiary amine. Friedel-Crafts cyclization and subsequent oxidation deliver isomerically pure jatrorrhizine. This synthesis of jatrorrhizine displayed a 20\% overall yield (Mori-Quiroz et al., 2018).

Microbial biosynthesis might become a fast and efficient way to obtain natural products. Identification and characterization of the biosynthetic pathway of jatrorrhizine is a prerequisite for its heterologous expression and production. Isoquinoline alkaloids are an important group of specialized plant metabolites. Biosynthesis proceeds by common early steps to form (S)reticuline (Figure 3). This pivotal intermediate is the branchpoint intermediate in the biosynthesis of many isoquinoline alkaloids (He et al., 2018). Sequentially, (S)-scoulerine is formed from $(S)$-reticuline by berberine bridge enzyme. Pyne et al. (2020) reported a yeast platform for high-level synthesis of tetrahydroisoquinoline alkaloids, and the production of the central intermediate (S)-reticuline increased to $4.6 \mathrm{~g} / \mathrm{L}$. However, the subsequent pathway leading to production jatrorrhizine remains unknown. Hagel and Facchini proposed that 3-O-demethylation of $(S)$-scoulerine combined with 2-Oand 9-O-methylation might lead to jatrorrhizine (Hagel and Facchini, 2010); enzymes that might catalyse these reactions have not been identified to date. Hence, more research needed to clarify the biosynthetic pathway of jatrorrhizine.

\section{PHARMACOLOGICAL ACTIVITIES OF JATRORRHIZINE}

\section{Anti-Obesity and Hypolipidemic Activity}

Obesity is a challenging health problem worldwide. Plants and their active phytochemical constituents are used as natural anti-obesity agents and dietary supplements for weight loss. Jatrorrhizine increased the expression of hepatic low-density lipoprotein receptor (LDLR) in Hep G2 cells in vitro and produced a significant reduction in cellular lipid accumulation (Zhou et al., 2014). Jatrorrhizine $(46.7 \mathrm{mg} / \mathrm{kg} \times$ day) was administered to high-fat and high-cholesterol (HFHC)-induced hyperlipidemic hamsters. This treatment reduced the serum total cholesterol (TC) and total triglyceride (TG), decreased the lowdensity lipoprotein cholesterol (LDL-C) levels, reduced protein levels of 3-hydroxy-3-methyl glutaryl coenzyme A reductase (HMGCR) and significantly increased the expression of cholesterol 7a-hydroxylase (CYP7A1) and LDLR, as well as elevated fecal excretion of cholesterol and TBA (He et al., 2016). In addition, jatrorrhizine decreased body weights of C57BL/6 mice on a HFHC diet and increased HDL-C levels (Yang et al., 2016). The anti-obesity and hypolipidemic effect of jatrorrhizine may thus be related to regulating the expression of LDLR, CYP7A1 and HMGCR, increasing lipid metabolism, and promoting excretion of TBA. All of these effects would lead to increase metabolism and excretion of cholesterol.

Jatrorrhizine ameliorated the pathophysiological changes observed in the livers of hyperlipidemic mice (e.g., swelling of hepatocytes, lipid accumulation, and so on) and caused in a significant decrease in serum aspartate transaminase (AST) and alanine aminotransferase (ALT) levels. Jatrorrhizine also downregulated the hepatic sterol regulatory element binding transcription factor 1c (SREBP-1c) and fatty acid synthase (FAS) levels and upregulated peroxisome proliferator activated receptor- $\alpha$ (PPAR- $\alpha$ ) and carnitine palmitoyl transferase $1 \mathrm{~A}$ (CPT1A) expression. Hence, jatrorrhizine may counter hyperlipidemia through inhibition of fatty acid synthesis and activation of fatty acid $\beta$ oxidation (Yang et al., 2016). Obesity is a complex disorder that significantly increases the risk of multiple metabolic disorders, such cardiovascular disease and diabetes (Karri et al., 2019). The clinical use of jatrorrhizine might helpful in the management of obesity and associated disorders. 


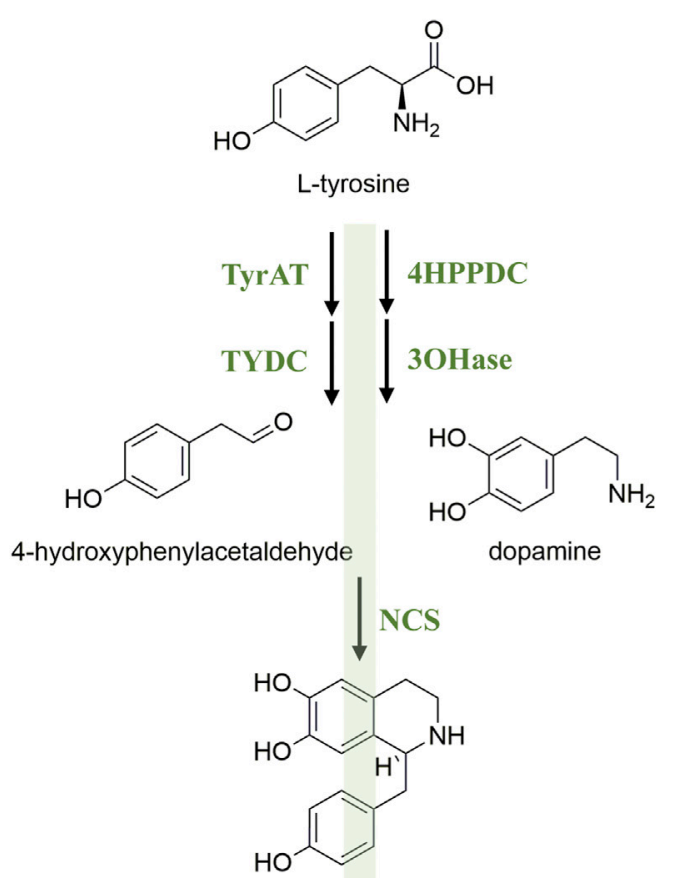

(S)-norcoclaurine<smiles>COc1cc2c(cc1O)/C(=C\c1ccc(O)cc1)NCC2</smiles>

(S)-coclaurine<smiles>COc1cc2c(cc1O)/C(=C/c1ccc(O)cc1)N(C)CC2</smiles>

(S)- $N$-methylorcoclaurine

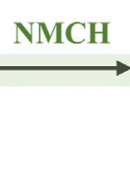<smiles>COc1cc2c(cc1O)CC[n+]1cc3c(OC)c(OC)ccc3cc1-2</smiles>

jatrorrhizine<smiles>COc1cc2c(cc1O)[C@@H]1Cc3ccc(OC)c(O)c3CN1CC2</smiles>

(S)-scoulerine<smiles>COC1=CC=C2C=C(CC1(Br)CBr)C(=C1c3cc(O)c(OC)cc3CCN1C)C2</smiles>

(S)-reticuline<smiles>C[13CH]=[18O]</smiles><smiles>COc1cc2c(cc1O)[C@@H](Cc1ccc(O)c(O)c1)N(C)CC2</smiles>

(S)-3'-hydroxy- $N$-methylorcoclaurine<smiles>COc1ccc2cc3[n+](cc2c1OC)CCc1cc2c(cc1-3)OCO2</smiles>
berberine<smiles>COc1ccc2c(c1OC)CN1CCc3cc4c(cc3[C@@H]2C1)OCO4</smiles>
(S)-canadine<smiles>COc1cc2c(cc1O)[C@@H]1Cc3ccc(OC)c(OC)c3CN1CC2[13CH3]</smiles>

(S)-tetrahydrocolumbamine

FIGURE 3 | Putative biosynthetic pathway of jatrorrhizine in plants.

\section{Anti-Diabetic Activity}

Type 2 diabetes mellitus (T2DM), an expanding global health problem, is characterized by insulin resistance and impaired insulin secretion (DeFronzo et al., 2015). Some botanical drugs containing jatrorrhizine, such as Coptidis Rhizoma, are widely used in traditional Chinese medicine for treating diabetes ( $\mathrm{Ma}$ et al., 2016; Meng et al., 2018).

The potential of jatrorrhizine as a hypoglycaemic agent was manifest by inhibition of $a$-glucosidase and aldose reductase (AR) (Patel MB. and Mishra S., 2012; Patel M. B. and Mishra S. M.,
2012). Jatrorrhizine displayed anti-diabetic activity in vitro (RINm5F cells and HepG2 cells) and in vivo (glucose-loaded rats and hyperlipidemic mice) via promoting insulin secretion, improving glucose tolerance and insulin sensitivity and inhibiting hepatic gluconeogenesis, thus improve postprandial hyperglycemia (Patel and Mishra, 2011; Chen et al., 2012; Yang et al., 2016; Li et al., 2020).

Jatrorrhizine protected rats with induced diabetes mellitus and restored vascular endothelial dysfunction through upregulating the Akt/AMPK/eNOS signaling pathway and reducing IL- $1 \beta$ and 
TABLE 2 | Anti-diabetic, antimicrobial, antiprotozoal, and central nervous system activities and mechanisms of jatrorrhizine in in vitro and in vivo assays.

$\begin{array}{llll}\text { Effect } \quad \text { Assay } & \text { Cell lines/model } & \text { Dosage } & \text { Type of } \\ \text { biological activity }\end{array}$

Anti-obesity and hypolipidemic activity

$\begin{array}{lll}\text { In vitro } & \text { HepG2 cells } & 15 \mu \mathrm{M} \\ \text { In vivo } & \begin{array}{l}\text { high-fat and high-cholesterol } \\ \text { (HFHC)-induced hyperlipidemic }\end{array} & 46.7 \mathrm{mg} / \mathrm{kg} \\ & \text { hamsters } & \\ \text { In vivo } & \text { C57BL } 6 \text { mice on a HFHC diet } & 20 \mathrm{mg} / \mathrm{kg} ; 100 \mathrm{mg} / \mathrm{kg}\end{array}$

Anti-diabetic activity

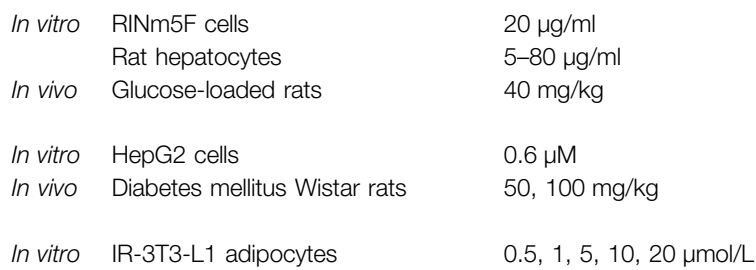

$\begin{array}{lll}\text { In vivo } & \text { Hyperlipidemia model mouse } & 100 \mathrm{mg} / \mathrm{kg} \\ & & \\ \text { In vitro } & \text { a-glucosidase } & \mathrm{IC}_{50}=36.25 \mu \mathrm{g} / \mathrm{ml} \\ \text { In vivo } & \text { Wistar rats } & 20 \mathrm{mg} / \mathrm{kg} \\ \text { In vitro } & \text { Lens AR isolated from Wistar rats } & \mathrm{IC}_{50}=3.23 \mathrm{mg} / \mathrm{ml}\end{array}$

Anti-microbial activity

Anti-protozoal activity

Central nervous system activities Anti-depression and In vitro anxiolytic activity

$\begin{array}{ll}\text { In vitro } & \text { Candida albicans SC5314 } \\ & \text { Candida auris } 12372 \\ \text { In vitro } & \begin{array}{l}\text { Propionibacterium acnes } \\ \text { coagulase-negative staphylococci } \\ \text { Candida tropicalis }\end{array} \\ & \\ \text { In vitro } & \begin{array}{l}\text { Staphylococcus aureus SMRSA } \\ \text { In vitro }\end{array} \\ & \begin{array}{l}\text { Staphylococcus aureus (MRSA) } \\ \text { In vivo }\end{array} \\ & \begin{array}{l}\text { Neutropenic murine thigh infection } \\ \text { model }\end{array} \\ \text { In vitro } & \begin{array}{l}\text { Neuraminidase of Clostridium } \\ \text { perfringens }\end{array}\end{array}$

Plasmodium falciparum $\mathrm{K} 1$ STIB 900

Leishmania donovani axenic

MHOM-ET-67/82

$\begin{array}{ll}\text { Madin-Darby canine kidney cell line } & \mathrm{IC}_{50}=2.31 \pm 0.21 \mu \mathrm{M} \\ & \mathrm{IC}_{50}=4.09 \pm 1.2 \mu \mathrm{M} \\ \text { hOCT2-transfected cells } & \mathrm{IC}_{50}=0.120 \mu \mathrm{M} \\ & \mathrm{IC}_{50}=0.819 \mu \mathrm{M} \\ \text { hOCT3-transfected cells } & \mathrm{IC}_{50}=0.278 \mu \mathrm{M}\end{array}$

$\mathrm{MIC}=256 \mu \mathrm{g} / \mathrm{ml}$ MIC of $25-50 \mu \mathrm{g} / \mathrm{ml}$ in coagulase-negative staphylococci

MIC of $125 \mu \mathrm{g} / \mathrm{ml}$ in C. tropicalis

$200 \mu \mathrm{g} / \mathrm{ml}$

$\mathrm{MIC}=64 \mathrm{mg} / \mathrm{L}$

25 or $50 \mathrm{mg} / \mathrm{kg}$ of of NFX

$\mathrm{IC}_{50}=37.0 \pm 1.8 \mu \mathrm{M}$ Trypanosoma brucei rhodesiense hepatic gluconeogenesis

$16 \mu \mathrm{g} / \mathrm{ml}$ in Candida albicans $64 \mu \mathrm{g} / \mathrm{ml}$ in Candida auris Propionibacterium acnes MIC of $100-250 \mu \mathrm{g} / \mathrm{ml}$ in jatrorrhizine and $100 \mathrm{mg} / \mathrm{kg}$

$\mathrm{IC}_{50}=0.24 \pm 0.002 \mu \mathrm{g} / \mathrm{m}$

$\mathrm{IC}_{50}=4.2 \pm 0.002 \mu \mathrm{g} / \mathrm{ml}$

$\mathrm{IC}_{50}=20.4 \pm 0.03 \mu \mathrm{g} / \mathrm{ml}$
Increased LDLR expression and decreased cellular lipid accumulation

Decreased TC, TG, TBA and increased the fecal excretion of cholesterol; upregulation of LDLR, CYP7A1 and HMGCR

Decreased body weight, TC, TG, LDL-C, AST, ALT and increased HDL-C;

amelioration of liver pathophysiological changes (swelling of hepatocytes and lipid accumulation); downregulation of SREBP-1c and FAS; upregulation of PPAR- $\alpha$ and CPT1A

Increased insulin secretion

Inhibition of hepatic gluconeogenesis Increased insulin secretion and inhibition of

Glucose-lowering effect

Reduced IL-1 $\beta$, TNF- $\alpha$ and upregulation of p-AKT, p-AMPK, eNOS

Amelioration of insulin resistance and

upregulation of IRS2, PI3KR1, p-AKT, p-AMPK and GLUT4/1/2

Reduced the body weight and improved glucose tolerance and insulin sensitivity Inhibitory activity against $a$-glucosidase

Inhibitory activity against aldose reductase

Inhibition of OCT2

Inhibition of OCT3

Decreased 5-HT and NE mediated by OCT2

Decreased 5-HT and NE mediated by OCT3

Zhou et al. (2014)

He et al. (2016)

Yang et al. (2016)

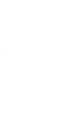

Patel and Mishra (2011)

Chen et al. (2012)

Wang et al.

(2017)

Zhu et al. (2018)

Yang et al. (2016)

Patel and Mishra (2012b)

Patel and Mishra (2012a)

Inhibitory activity against Candida albicans Liu et al. (2020) and Candida auris

Induced cell wall remodeling

Inhibitory activity against Propionibacterium acnes, coagulase-negative staphylococci

Slobodníková and Candida tropicalis

Inhibition of antibiotic resistant

Ali et al. (2013)

Staphylococcus aureus

Inhibitory activity against methicillin-resistant Yu et al. (2019) Staphylococcus aureus

Inhibitory activity against bacterial NA

Kim et al. (2014)

Anti-plasmodial, anti-trypanosomal and antileishmanial activity

Malebo et al. (2013)

(Continued on following page) 
TABLE 2 | (Continued) Anti-diabetic, antimicrobial, antiprotozoal, and central nervous system activities and mechanisms of jatrorrhizine in in vitro and in vivo assays.

Effect Assay Cell lines/model Dosage Refences

biological activity

\begin{tabular}{|c|c|c|c|c|c|}
\hline & & & $\mathrm{IC}_{50}=0.184 \mu \mathrm{M}$ & & \\
\hline & & PMAT-transfected cells & $\begin{array}{l}\mathrm{IC}_{50}=3.84 \mu \mathrm{M} \\
\mathrm{IC}_{50}=2.99 \mu \mathrm{M}\end{array}$ & $\begin{array}{l}\text { Decreased } 5-\mathrm{HT} \text { and reduce NE uptake } \\
\text { mediated by PMAT }\end{array}$ & \\
\hline & In vivo & Male ICR albino mice & $5,10,20 \mathrm{mg} / \mathrm{kg}$ of i.p & $\begin{array}{l}\text { Reduced the duration of immobility in mouse } \\
\text { tail suspension test }\end{array}$ & \\
\hline & In vitro & Monoamine oxidase-A & $\mathrm{IC}_{50}=57.73 \pm 5.26 \mu \mathrm{M}$ & Inhibitory activity against MAO-A enzyme & $\begin{array}{l}\text { Zhang et al. } \\
(2019)\end{array}$ \\
\hline & In vitro & MAO-A from rat brain mitochondria & $\mathrm{IC}_{50}=4 \mu \mathrm{M}$ & & Kong et al. (2001) \\
\hline Anti-Alzheimer's & In vitro & Acetylcholinesterase & $\mathrm{IC}_{50}=0.57 \mu \mathrm{M}$ & Inhibitory activity against $\mathrm{AChE}$ & Lin et al. (2020) \\
\hline disease & In vitro & Recombinant human IDO-1 & $\mathrm{IC}_{50}=206 \mu \mathrm{M}$ & Inhibitory activity against IDO-1 & Yu et al. (2010) \\
\hline & & HEK 293-hIDO1 cells & $\mathrm{IC}_{50}=17.8 \mu \mathrm{M}$ & & \\
\hline & In vitro & HT22 cells & $5,10 \mu \mathrm{mol} / \mathrm{L}$ & $\begin{array}{l}\text { Antioxidation and inhibition of the mitogen- } \\
\text { activated protein kinases (MAPK) pathways }\end{array}$ & Jiang et al. (2015) \\
\hline & & $\begin{array}{l}\text { SH-SY5Y cells induced by } A \beta \\
25-35\end{array}$ & $10 \mathrm{mM}$ & $\begin{array}{l}\text { Upregulation of miR-223-3p, inhibition of the } \\
\text { HDAC4 expression, suppression of } \\
\text { apoptosis and OS, and improved cell } \\
\text { proliferation }\end{array}$ & $\begin{array}{l}\text { Duan and Chen } \\
(2021)\end{array}$ \\
\hline & In vivo & APP/PS1 transgenic mice & $5,10 \mathrm{mg} / \mathrm{kg}$ & $\begin{array}{l}\text { Decreased the levels of } A \beta \text { plaques in the } \\
\text { cortex and hippocampus, alleviated the } \\
\text { learning and memory deficits }\end{array}$ & $\begin{array}{l}\text { Wang et al. } \\
\text { (2019b) }\end{array}$ \\
\hline & In vivo & C57BL/6 wild-type (WT) mice & High dose & $\begin{array}{l}\text { Regulated the abundance of the microbiota } \\
\text { and increased the amounts of beneficial } \\
\text { bacteria }\end{array}$ & \\
\hline Neuroprotective effect & In vitro & $\begin{array}{l}\mathrm{H}_{2} \mathrm{O}_{2} \text {-induced rat } \\
\text { pheochromocytoma line PC12 } \\
\text { injury }\end{array}$ & $0.01-10.0 \mu \mathrm{M}$ & $\begin{array}{l}\text { Increased cell viability and activities of SOD, } \\
\mathrm{HO}-1 \text {; decreased LDH, MDA and ROS; } \\
\text { inhibited apoptosis by inhibiting caspase-3 } \\
\text { activation }\end{array}$ & Luo et al. (2011) \\
\hline $\begin{array}{l}\text { Treatment of } \\
\text { ischaemic stroke }\end{array}$ & In vitro & mouse brain endothelial cells & $5,10,20 \mu \mathrm{M}$ & $\begin{array}{l}\text { Reduced t-BHP-induced apoptosis; } \\
\text { decreased ROS, MDA and } 4-H N E ; \text { improved } \\
\text { MMP and eNOS; inhibit IL- } 1 \beta \text {, TNF- } \alpha \text { and IL- } \\
6 \text {; prevented decreases in PPAR- } \gamma\end{array}$ & Wu et al. (2020) \\
\hline Anti-parkinsonian & In vitro & MAO-B from rat brain mitochondria & $\mathrm{IC}_{50}=62 \mu \mathrm{M}$ & Inhibitory activity against MAO-B enzyme & Kong et al. (2001) \\
\hline & In vivo & $\begin{array}{l}\text { Titanium Particle-induced murine } \\
\text { calvarial osteolytic model (C57BL/6 } \\
\text { mice) }\end{array}$ & $100 \mathrm{mg} / \mathrm{kg}$ & $\begin{array}{l}\text { Increased } \mathrm{BMD} \text { and } \mathrm{BV} / \mathrm{TV} \text {, reduced bone } \\
\text { erosion and the number of osteoclasts }\end{array}$ & Li et al. (2018) \\
\hline & In vitro & $\begin{array}{l}\text { bone marrow-derived } \\
\text { macrophages }\end{array}$ & $5-20 \mu \mathrm{M}$ & $\begin{array}{l}\text { Inhibited RANKL-induced osteoclast } \\
\text { formation and bone resorption by the } \\
\text { suppression of MAPKs signaling pathways } \\
\text { and downregulation of NFATc1, TRAP, CTR } \\
\text { and CTSK }\end{array}$ & \\
\hline & In vivo & collagen-induced arthritis $(\mathrm{CIA})$ rats & $20 \mathrm{mg} / \mathrm{kg} ; 50 \mathrm{mg} / \mathrm{kg}$ & $\begin{array}{l}\text { Inhibited NF- } \kappa \text { B and MAPKs stimulated by } \\
\text { TNF- } \alpha \text { and inhibited bone destruction }\end{array}$ & Qiu et al. (2018) \\
\hline Other pharmacological & ictivities & & & & \\
\hline $\begin{array}{l}\text { Effect on } \\
\text { gastrointestinal tracts }\end{array}$ & In vitro & $\begin{array}{l}\text { Gastrointestinal tract smooth } \\
\text { muscles isolated from rat }\end{array}$ & $100 \mu \mathrm{M}$ & $\begin{array}{l}\text { Increased the amplitude of contractile } \\
\text { responses of jejunum and ileum longitudinal } \\
\text { muscles, antrum circular muscles and } \\
\text { smooth muscles in distal colon, and } \\
\text { activated acetylcholine receptors }\end{array}$ & Yuan et al. (2011) \\
\hline & In vivo & Male Wistar rats & $0.1,0.3$ and $1 \mathrm{mg} / \mathrm{kg}$ & $\begin{array}{l}\text { Offset of postoperative ileus-induced } \\
\text { delayed gastric emptying and intestinal } \\
\text { transit }\end{array}$ & $\begin{array}{l}\text { Zhang et al. } \\
(2012)\end{array}$ \\
\hline $\begin{array}{l}\text { Hepatoprotective } \\
\text { activity }\end{array}$ & In vitro & $\begin{array}{l}\text { t-BHP-injured rat hepatocyte BRL- } \\
3 \text { A cells }\end{array}$ & $\mathrm{EC}_{50}=15.7 \pm 3.3 \mu \mathrm{M}$ & Decreased the release of $\mathrm{LDH}$ & $\begin{array}{l}\text { Wang et al. } \\
(2016)\end{array}$ \\
\hline
\end{tabular}

tumor necrosis factor $\alpha(\mathrm{TNF}-\alpha)$ in blood vessels (Wang, et al., 2017). The alkaloid regulated glucose uptake and utilization and reduced insulin resistance through upregulating the expression of insulin receptor substrate 2 (IRS2), phosphoinositide-3-kinase regulatory subunit 1 (PI3KR1), phosphorylated protein kinase $B$ (p-AKT), phospho-AMP-activated protein kinase (p-AMPK) and glucose transporter 4/1/2 (GLUT4/1/2) (Zhu et al., 2018). Jatrorrhizine, a primary active component of Coptidis Rhizoma, displayed potent inhibition of gut microbiota modulation and reduction of blood glucose in $\mathrm{d} b / d b$ mice (Lyu et al., 2021).

Jatrorrhizine is thus considered to be an active ingredient with multiple manners that reduce hypoglycaemia (Table 2). 
TABLE 3 | The anti-cancer effects of jatrorrhizine and its complexes.

\begin{tabular}{|c|c|c|c|c|c|c|}
\hline $\begin{array}{l}\text { Cancer } \\
\text { type }\end{array}$ & $\begin{array}{c}\text { Cells or } \\
\text { tumor models }\end{array}$ & Application & Dosage & Suppressive effect & Mechanisms & References \\
\hline \multirow[t]{2}{*}{ Melanoma } & $\begin{array}{l}\text { C8161 human metastatic melanoma } \\
\text { cell line }\end{array}$ & In vitro & $\begin{array}{l}80,160 \\
320 \mu \mathrm{mol} / \mathrm{L}, 48 \mathrm{~h}\end{array}$ & $\begin{array}{l}\text { Inhibition of cell } \\
\text { proliferation and } \\
\text { neovascularization }\end{array}$ & $\begin{array}{l}\text { Cell cycle arrest, and } \\
\text { upregulation of p21 and } \\
\text { p27, p53 }\end{array}$ & $\begin{array}{l}\text { Liu et al. } \\
\text { (2013) }\end{array}$ \\
\hline & $\begin{array}{l}\text { Matrigel plug assay in BALB/C nude } \\
\text { mice }\end{array}$ & In vivo & $50 \mu \mathrm{g}, 14$ days & & $\begin{array}{l}\text { Reduced numbers of blood } \\
\text { vessels }\end{array}$ & \\
\hline \multirow[t]{4}{*}{$\begin{array}{l}\text { Colorectal } \\
\text { cancer }\end{array}$} & SW480 human colon cancer cell line & In vitro & $\begin{array}{l}25-200 \mu \mathrm{g} / \mathrm{ml}, 24 \\
\text { and } 48 \mathrm{~h}\end{array}$ & $\begin{array}{l}\text { Inhibition of cell } \\
\text { proliferation and cell } \\
\text { viability }\end{array}$ & & $\begin{array}{l}\text { Singh et al. } \\
(2016)\end{array}$ \\
\hline & SW620 colorectal cancer cell line & In vitro & $100 \mu \mathrm{M}$ & $\begin{array}{l}\text { Inhibition of cell } \\
\text { proliferation }\end{array}$ & $\begin{array}{l}\text { Formation of complexes with } \\
\text { oncogene KRAS promoter NHE } \\
\text { G-quadruplex }\end{array}$ & $\begin{array}{l}\text { Wen and Xie } \\
(2017)\end{array}$ \\
\hline & $\begin{array}{l}\text { Human colorectal carcinoma cell } \\
\text { lines HCT-116 and HT-29 }\end{array}$ & In vitro & $\begin{array}{l}\mathrm{IC}_{50} \text { of HCT-116: } \\
6.99 \pm \\
0.29 \mu \mathrm{M}, 72 \mathrm{~h} \\
\mathrm{IC}_{50} \text { of HT-29: } \\
5.46 \pm \\
0.13 \mu \mathrm{M}, 72 \mathrm{~h} \\
5,10,15 \mu \mathrm{M} \\
24,48, \text { and } 72 \mathrm{~h}\end{array}$ & $\begin{array}{l}\text { Suppression of cell growth } \\
\text { and proliferation, inhibit } \\
\text { migration and invasion }\end{array}$ & $\begin{array}{l}\text { Promotion of apoptosis, } \\
\text { induced nuclear morphological } \\
\text { changes, block of cell cycle in S } \\
\text { phase, repressed } \Delta \Psi \mathrm{m} \text {, } \\
\text { reduced } \beta \text {-catenin, F-actin and } \\
\mathrm{N} \text {-cadherin, and increased } \\
\text { GSK-3 } \beta \text { and E-cadherin }\end{array}$ & $\begin{array}{l}\text { Wang et al. } \\
\text { (2019a) }\end{array}$ \\
\hline & $\begin{array}{l}\text { HCT-116 nude mice xenograft } \\
\text { model }\end{array}$ & In vivo & $5 \mathrm{mg} / \mathrm{kg}, 4$ weeks & $\begin{array}{l}\text { Inhibition of tumor growth } \\
\text { and metastasis }\end{array}$ & $\begin{array}{l}\text { Reduced tumor volume and } \\
\text { weight, upregulation of GSK-3 } \beta \\
\text { and E-cadherin, and } \\
\text { downregulation of } \beta \text {-catenin, } \\
\text { F-actin and } \mathrm{N} \text {-cadherin }\end{array}$ & \\
\hline Liver cancer & $\begin{array}{l}\text { HepG2 and HCCLM3 liver cancer } \\
\text { cells }\end{array}$ & In vitro & $\begin{array}{l}0.5-16.0 \mu \mathrm{M} \\
48 \mathrm{~h}\end{array}$ & $\begin{array}{l}\text { Inhibition of cell viability, } \\
\text { proliferation, invasion and } \\
\text { migration }\end{array}$ & $\begin{array}{l}\text { Promotion of apoptosis, } \\
\text { downregulation of miR-221-3p } \\
\text { and miR-15b-5p expression, } \\
\text { and upregulation of Axin2 } \\
\text { protein }\end{array}$ & $\begin{array}{l}\text { Deng and } \\
\text { Wan (2021) }\end{array}$ \\
\hline \multirow[t]{2}{*}{$\begin{array}{l}\text { Breast } \\
\text { cancer }\end{array}$} & $\begin{array}{l}\text { MDA-MB- } 231 \text { triple-negative breast } \\
\text { cancer cell line, MCF-7 estrogen } \\
\text { receptor positive breast carcinoma } \\
\text { cell line, and } 4 \mathrm{~T} 1 \text { mouse } \\
\text { mammarycarcinoma cells }\end{array}$ & In vitro & $\begin{array}{l}10,20,30 \mu \mathrm{M} \\
24 \text { and } 48 \mathrm{~h}\end{array}$ & $\begin{array}{l}\text { Inhibition of cell } \\
\text { proliferation }\end{array}$ & $\begin{array}{l}\text { Repressed } \Delta \Psi \mathrm{m} \text {, suppressed } \\
\text { Wnt/ } \beta \text {-catenin signaling and } \\
\text { EMT expression via targeted } \\
\text { TNIK, upregulation of GSK-3 } \beta \\
\text { and E-cadherin, and } \\
\text { downregulation of } \beta \text {-catenin, } \\
\text { F-actin and N-cadherin, up- } \\
\text { regulate Bax, downregulation of } \\
\text { Bcl-2, decreased Procaspase- } \\
3 \text {, Procaspase-8, Procaspase-9 } \\
\text { and PARP }\end{array}$ & $\begin{array}{l}\text { Sun et al. } \\
(2019)\end{array}$ \\
\hline & $\begin{array}{l}\text { Orthotopic } 4 \mathrm{~T} 1 \text { tumour bearing } \\
\text { mouse }\end{array}$ & In vivo & $\begin{array}{l}2.5 \mathrm{mg} / \mathrm{kg} \mathrm{b.w} \\
5 \mathrm{mg} / \mathrm{kg} \mathrm{b.w} \\
4 \text { weeks }\end{array}$ & $\begin{array}{l}\text { Inhibition of the growth and } \\
\text { metastasis }\end{array}$ & $\begin{array}{l}\text { Reduced tumor growth rate and } \\
\text { improve survival rate, } \\
\text { upregulation of GSK-3 } \beta \text { and } \\
\text { E-cadherin, downregulation of } \\
\text { TNIK, p-TNIK, F-actin, } \\
\beta \text {-catenin, and N-cadherin }\end{array}$ & \\
\hline \multirow[t]{2}{*}{$\begin{array}{l}\text { Thyroid } \\
\text { cancer }\end{array}$} & $\begin{array}{l}\text { SW1736, BHP7-13, and } 8305 \mathrm{C} \text { cell } \\
\text { lines }\end{array}$ & In vitro & $\begin{array}{l}1.5,3,6,12,24 \\
48 \mu \mathrm{M}, 48 \mathrm{~h}\end{array}$ & $\begin{array}{l}\text { Inhibition of cell } \\
\text { proliferation }\end{array}$ & $\begin{array}{l}\text { Cell cycle arrest, increased } \\
\text { accumulation of ROS, promoted } \\
\text { the levels of cleaved caspase-3 } \\
\text { and p-H2AX, suppressed pS6, } \\
\text { p-ERK1/2, p-4E-BP1, p-AKT, } \\
\text { KU70, ERCC1, RAD51 and } \\
\text { KU80, downregulation of the } \\
\text { PI3K/AKT/mTOR signaling } \\
\text { pathway and promotion of DNA } \\
\text { damage }\end{array}$ & $\begin{array}{l}\text { Lu et al. } \\
(2020)\end{array}$ \\
\hline & Female athymic nude mice & In vivo & $\begin{array}{l}24.0 \mathrm{mg} / \mathrm{kg} \\
14 \text { days }\end{array}$ & Inhibition of tumor growth & $\begin{array}{l}\text { Increased } \mathrm{pH} 2 \mathrm{AX} \text { and } \\
\text { acetylated histone } \mathrm{H} 3 \text {, histone } \\
\mathrm{H} 4 \text { and cleaved caspase- } 3\end{array}$ & \\
\hline
\end{tabular}

(Continued on following page) 
TABLE 3 | (Continued) The anti-cancer effects of jatrorrhizine and its complexes.

\begin{tabular}{|c|c|c|c|c|c|c|}
\hline $\begin{array}{l}\text { Cancer } \\
\text { type }\end{array}$ & $\begin{array}{c}\text { Cells or } \\
\text { tumor models }\end{array}$ & Application & Dosage & Suppressive effect & Mechanisms & References \\
\hline \multirow[t]{2}{*}{$\begin{array}{l}\text { HeLa } \\
\text { cancer }\end{array}$} & Human cervical (HeLa) cell line & In vitro & $\begin{array}{l}\text { Pt1: } I C_{50}= \\
15.01 \pm 1.05 \mathrm{nM} \\
\text { Pt2: } 1.00 \pm \\
0.17 \mathrm{nM}\end{array}$ & $\begin{array}{l}\text { Inhibition of cell } \\
\text { proliferation }\end{array}$ & $\begin{array}{l}\text { Targeting p53 and telomerase, } \\
\text { repressed telomerase related- } \\
\text { proteins (c-myc and hTERT), } \\
\text { promoted DNA damage } \\
\text { (activation of 53BP1, H2A.X, } \\
\text { TRF1, and TRF2), decreased } \\
\Delta \Psi \mathrm{m} \text {, sub-G1 phase arrest and } \\
\text { cell apoptosis }\end{array}$ & $\begin{array}{l}\text { Qin et al. } \\
(2019 b)\end{array}$ \\
\hline & $\begin{array}{l}\text { Human cervical (HeLa)-xenograft } \\
\text { model }\end{array}$ & In vivo & $\begin{array}{l}\text { Pt2: } 2.0 \mathrm{mg} / \mathrm{kg} \\
\text { per } 2 \text { days, } \\
21 \text { days }\end{array}$ & Inhibition of tumor growth & & \\
\hline \multirow[t]{2}{*}{$\begin{array}{l}\text { Bladder } \\
\text { cancer }\end{array}$} & Human bladder T-24 tumor cell & In vitro & $\begin{array}{l}\text { Pt1:100.0 nM, } 6 \mathrm{~h} \\
\text { Pt2: } 10.0 \mathrm{nM}, 6 \mathrm{~h}\end{array}$ & $\begin{array}{l}\text { Inhibition of cell } \\
\text { proliferation }\end{array}$ & $\begin{array}{l}\text { Induced TRF1- and TRF2- } \\
\text { telomeres damage, decreased } \\
\text { hTERT and c-myc levels, } \\
\text { increased ROS, cytochrome c, } \\
\text { caspase-9, caspase-3, Apaf-1, } \\
\text { inhibited Bcl-2, and cell cycle } \\
\text { arrest (suppression of cyclin D1 } \\
\text { and CDK2) }\end{array}$ & $\begin{array}{l}\text { Qin et al. } \\
\text { (2019a) }\end{array}$ \\
\hline & $\begin{array}{l}\text { T-24 xenograft mouse models (nude } \\
\text { mice) }\end{array}$ & In vivo & $\begin{array}{l}\text { Pt1: } 2.0 \mathrm{mg} / \mathrm{kg} \\
\text { per } 2 \text { days } \\
\text { Pt2: } 2.0 \mathrm{mg} / \mathrm{kg} \\
\text { per } 2 \text { days }\end{array}$ & Inhibition of tumor growth & & \\
\hline
\end{tabular}

However, a comparative study of jatrorrhizine and existing antidiabetic drugs is not available. Systematic clinical research and molecular studies of jatrorrhizine are still needed to elucidate definite mechanism of action. It is reported that other alkaloids in Coptidis Rhizoma also exhibit anti-diabetic effects, such as berberine, coptisine and palmatine (Lyu et al., 2021). The synergy between this natural metabolite with other alkaloids in Coptidis Rhizoma is of special interest, including interacts with berberine, coptisine and palmatine.

\section{Anti-Microbial and Anti-protozoal Activity}

Jatrorrhizine, in plants such as Mahonia aquifolium (Pursh) Nutt., Berberis brevissima Jafri and Coptis chinensis Franch. (Slobodníková et al., 2004; Ali et al., 2013; Tseng et al., 2021), is a notable among natural products for its varied anti-microbial properties. This metabolite strongly inhibited the growth of some bacteria, such as Candida albicans SC5314 (MIC $=256 \mu \mathrm{g} / \mathrm{ml})$, Candida auris 12372 (MIC $=256 \mu \mathrm{g} / \mathrm{ml})$, Candida tropicalis $(\mathrm{MIC}=125 \mu \mathrm{g} / \mathrm{ml})$, Propionibacterium acnes (MIC between 25 and $50 \mu \mathrm{g} / \mathrm{ml}$ ), coagulase-negative staphylococci (MIC between 100 and $250 \mu \mathrm{g} / \mathrm{ml})$ and Staphylococcus aureus $(200 \mu \mathrm{g} / \mathrm{ml})$ (Slobodníková et al., 2004; Ali et al., 2013; Liu et al., 2020). This alkaloid induced cell wall remodeling at $16 \mu \mathrm{g} / \mathrm{ml}$ in Candida albicans and $64 \mu \mathrm{g} / \mathrm{ml}$ in Candida auris (Liu et al., 2020). The mechanism underlying the antimycotic effect was inhibition of drug efflux and expression of the NorA multi-drug efflux pump (Yu et al., 2019). Further, a combination of jatrorrhizine (25 or $50 \mathrm{mg} / \mathrm{kg}$ ) and norfloxacin (NFX, $100 \mathrm{mg} / \mathrm{kg}$ ) significantly decreased bacterial count in a murine thigh infection model, suggesting in vivo synergistic bactericidal activity. Moreover, the combination of five berberine alkaloids (berberine: coptisine: jatrorrhizine: palmatine: epiberberine $=0.702: 0.863: 1: 0.491$ :
0.526) exhibited broad-spectrum antibacterial activity, and this activity was verified in vivo using cyclophosphamideimmunocompromised mouse model and in vitro against Escherichia coli, Staphylococcus aureus, Staphylococcus dysenteriae, and Staphylococcus pneumonia. Hence, jatrorrhizine may act synergistically with other alkaloids (Luo et al., 2013). Moreover, jatrorrhizine showed a synergistic effect with colistin antibacterial activity against carbapenem-resistant Klebsiella pneumoniae, exhibiting one-to two-fold reductions of colistin MIC (Tseng et al., 2021).

Neuraminidase (NA) is a novel target for the development of therapeutic agents to treat bacterial or viral infections (Kim et al., 2014; Luo et al., 2020). As documented in literature, jatrorrhizine showed inhibitory activity on bacterial NA with an $\mathrm{IC}_{50}$ value of $37.0 \pm 1.8 \mu \mathrm{M}$ and suppressed viral NA activity against rvH1N1 and $\mathrm{H} 5 \mathrm{~N} 1$ with $\mathrm{IC}_{50}$ values of $66.2 \pm 4.2 \mu \mathrm{M}$ and $76.3 \pm 2.1 \mu \mathrm{M}$ (Kim et al., 2014). Molecular modelling and docking studies indicated that jatrorrhizine might be a potent agent against transmembrane protease serine 2 (TMPRSS2) enzyme for treating SARS-CoV-2 (Pooja et al., 2021). It bound to human immunodeficiency virus-1 (HIV-1) as an effective inhibitor of HIV (Namthabad and Mamidala, 2014). Therefore, jatrorrhizine is a promising therapeutic agent and a natural metabolite of the combination therapy for microbial diseases.

Annickia affinis (Exell) Versteegh and Sosef and Annickia chlorantha (Oliv.) Setten and Maas containing jatrorrhizine are used for the treatment of malaria across tropical Africa (Olivier et al., 2015; Odoh et al., 2018). In vitro antiprotozoal studies on jatrorrhizine have shown its anti-plasmodial activity against multi-drug resistant strains of Plasmodium falciparum K1 $\left(\mathrm{IC}_{50}=0.24 \pm 0.002 \mu \mathrm{g} / \mathrm{ml}\right)$, anti-trypanosomal activity against the Trypanosoma brucei rhodesiense STIB $900\left(\mathrm{IC}_{50}=4.2 \pm\right.$ 
$0.002 \mu \mathrm{g} / \mathrm{ml}$ ) and anti-leishmanial activity against Leishmania donovani axenic MHOM-ET-67/82 strain $\left(\mathrm{IC}_{50}=20.4 \pm\right.$ $0.03 \mu \mathrm{g} / \mathrm{ml}$ ) (Malebo et al., 2013).

In vivo validation of naturally occurring anti-microbials and the development of effective alternatives to anti-biotics is crucial in the current era of microorganism resistance. Several studies report anti-microbial and anti-protozoal activity of jatrorrhizine in vitro, but clinical efficacy, therapeutic doses, safety and mechanisms remain largely unknown.

\section{Effects on the Central Nervous System Anti-depressant Activity}

Jatrorrhizine demonstrated anti-depressant activity via several targets in anti-depressant therapeutics. It showed strong inhibitory activity against monoamine oxidase A (MAO-A) $\left(\mathrm{IC}_{50}=4 \mu \mathrm{M}\right)$. This inhibitory activity was greater than that of berberine $\left(\mathrm{IC}_{50}=126 \mu \mathrm{M}\right)$, which lacks the phenolic hydroxyl of jatrorrhizine (Kong et al., 2001; Zhang et al., 2019). Furthermore, several studies have shown that organic cation transporters (OCTs) play roles in anti-anxiety and anti-depressant processes (Bacq et al., 2012) and plasma membrane monoamine transporter (PMAT) is a novel anti-depressant target. Jatrorrhizine was proved to be a high-affinity substrate for OCTs and a potent inhibitor of OCT2 $\left(\mathrm{IC}_{50}=2.31 \pm 0.21 \mu \mathrm{M}\right)$ and OCT3 $\left(\mathrm{IC}_{50}=4.09 \pm 1.2 \mu \mathrm{M}\right)$ (Li et al., 2016). Moreover, jatrorrhizine strongly reduced serotonin (5-HT) and norepinephrine (NE) uptake mediated by hOCT2, hOCT3, and hPMAT in vitro. Meanwhile, jatrorrhizine reduced 5-HT and NE uptake at $50 \mu \mathrm{M}$ in mouse synaptosomes, and reduced the duration of immobility and reversed the effect of stress in tail suspension tests, consistent with an anti-depressant effect. However, more in vivo experiments are needed to verify and clarify the complex anti-depressant activity of jatrorrhizine.

\section{Anti-Alzheimer's Disease}

The Alzheimer's disease $(\mathrm{AD})$ is currently attributed to extracellular aggregates of amyloid $\beta(\mathrm{A} \beta)$ plaques and intracellular neurofibrillary tangles in cortical and limbic areas of the human brain (Tiwari et al., 2019). Defects in acetylcholine and cholinergic neurotransmission can be observed along with the accumulation of $\beta$-amyloid. The use of acetylcholinesterase (AChE) inhibitors, which activate central cholinergic function, is a treatment strategy for $\mathrm{AD}$. Jatrorrhizine demonstrated inhibitory activity against $\mathrm{AChE}$ with $\mathrm{IC}_{50}$ values of $0.57 \mu \mathrm{M}$ (Lin et al., 2020), 106.1 $\mu \mathrm{M}$ (Zhao et al., 2016) and 2.08 $\mu \mathrm{M}$ (Xiao et al., 2011), respectively. The differences in these values might be explained by the different sources and concentrations of the enzyme and substrate used for testing. Further, a jatrorrhizine derivative with $-\mathrm{NH}_{2}$ linked at the 3-position $\left(\mathrm{IC}_{50}=0.301 \mu \mathrm{M}\right)$ exhibited the greater $\mathrm{AChE}$ inhibitory activity than jatrorrhizine $\left(\mathrm{IC}_{50}=\right.$ $0.872 \mu \mathrm{M}$ ) (Jiang et al., 2017). Hence, structural modification of jatrorrhizine may be effective for modulating its activity.

Indoleamine 2, 3-dioxygenase 1 (IDO-1) is a rate-limiting enzyme in the kynurenine pathway of tryptophan metabolism. The accumulation of a downstream neurotoxic metabolite via overexpression or over activation of IDO1 is involved in neurodegenerative disease (Zhang et al., 2017; Rohrig et al.,
2019). Jatrorrhizine was able to irreversibly inhibit IDO1, and had $\mathrm{IC}_{50}$ values of $206 \mu \mathrm{M}$ (recombinant human IDO-1) and $17.8 \mu \mathrm{M}$ (in HEK 293-hIDO1 cells) (Yu et al., 2010).

In vivo treatment of $\mathrm{APP} / \mathrm{PS} 1$ transgenic mice with $5 \mathrm{mg} / \mathrm{kg}$ or $10 \mathrm{mg} / \mathrm{kg}$ jatrorrhizine reduced levels of $\mathrm{A} \beta$ plaques in the cortex and hippocampus, and alleviated the learning and memory deficits (Wang S. et al., 2019). Learning and memory impairment in AD is related to dysfunction in gut microbiota (Vogt et al., 2017). Microbial colonies of APP/PS1 mice showed altered composition compared to C57BL/6 wild-type (WT) mice. High dose jatrorrhizine treatment modulated microbiota populations and enriched the numbers of beneficial bacteria, such as Faecalibaculum, Lactobacillus acidophilus and Bifidobacterium (Wang S. et al., 2019). Thus, jatrorrhizine might affect the learning and memory capabilities by regulating the intestinal flora.

Neuroprotective effects of jatrorrhizine are mainly attributed to its anti-oxidant property and anti-apoptosis activity. The alkaloid alleviates alleviated oxidative damage and suppresses neuronal apoptosis. Jatrorrhizine exhibited neuroprotective activity on okadaic acid (OA)-induced cytotoxicity and apoptosis in HT22 cells. This effect ascribed to increase cell viability, enhance anti-oxidant status (SOD and GSH) and maintenance of mitochondrial membrane potential (MMP). Reduced lactate dehydrogenase $(\mathrm{LDH})$ release, lipid peroxidation (MDA) levels and reactive oxygen species (ROS) were also observed. Other responses included downregulation of expression of phosphorylated extracellular signal-regulated kinases 1/2 (p-ERK1/2), phosphorylated c-Jun N-terminal kinases (p-JNK) and phosphorylated p38 (p-p38), along with upregulation of $\mathrm{B}$ cell lymphoma 2 (Bcl-2), reduction in cleaved caspase- 3 and BCL-2-associated X protein (Bax) levels, and inhibition of NF- $\mathrm{kB}$ p65 subunit activation (Jiang et al., 2015). A possible mechanism was inhibition of mitogen-activated protein kinase (MAPK) pathways. Similarly, jatrorrhizine was effective in mitigating hydrogen peroxide $\left(\mathrm{H}_{2} \mathrm{O}_{2}\right)$-induced rat pheochromocytoma PC12 injury via reducing oxidative stress and inhibiting apoptosis (Luo et al., 2011). Furthermore, treatment with jatrorrhizine $(10 \mathrm{mM})$ alleviated $\mathrm{A} \beta$ 25-35induced nerve cell injury through upregulating miR-223-3p and inhibiting histone deacetylase 4 (HDAC4) expression. The alkaloid also suppressed apoptosis and oxidative stress (OS) and improved SH-SY5Y cell proliferation (Duan and Chen, 2021).

\section{Other Effects on the Central Nervous System}

Jatrorrhizine might have therapeutic potential for ischaemic stroke associated with endothelial dysfunction. The alkaloid produced protective effect in mouse brain endothelial cells (MBECs) treated with tert-butyl hydroperoxide (t-BHP) via reducing cell apoptosis, inhibiting oxidative damage and ameliorating mitochondrial dysfunction. Jatrorrhizine also prevented the expression of IL-1 $\beta$, TNF- $\alpha$ and IL-6, and upregulated endothelial nitric oxide synthase (eNOS) and prevented decreases in PPAR $-\gamma$ protein expression in MBECs (Wu et al., 2020). Jatrorrhizine also non-competitively inhibited MAO-B from rat brain mitochondria with an $\mathrm{IC}_{50}$ value of $62 \mathrm{mM}$ (Kong et al., 2001). This activity was intended to be helpful for the prevention and adjunct treatment of Parkinson' disease. 


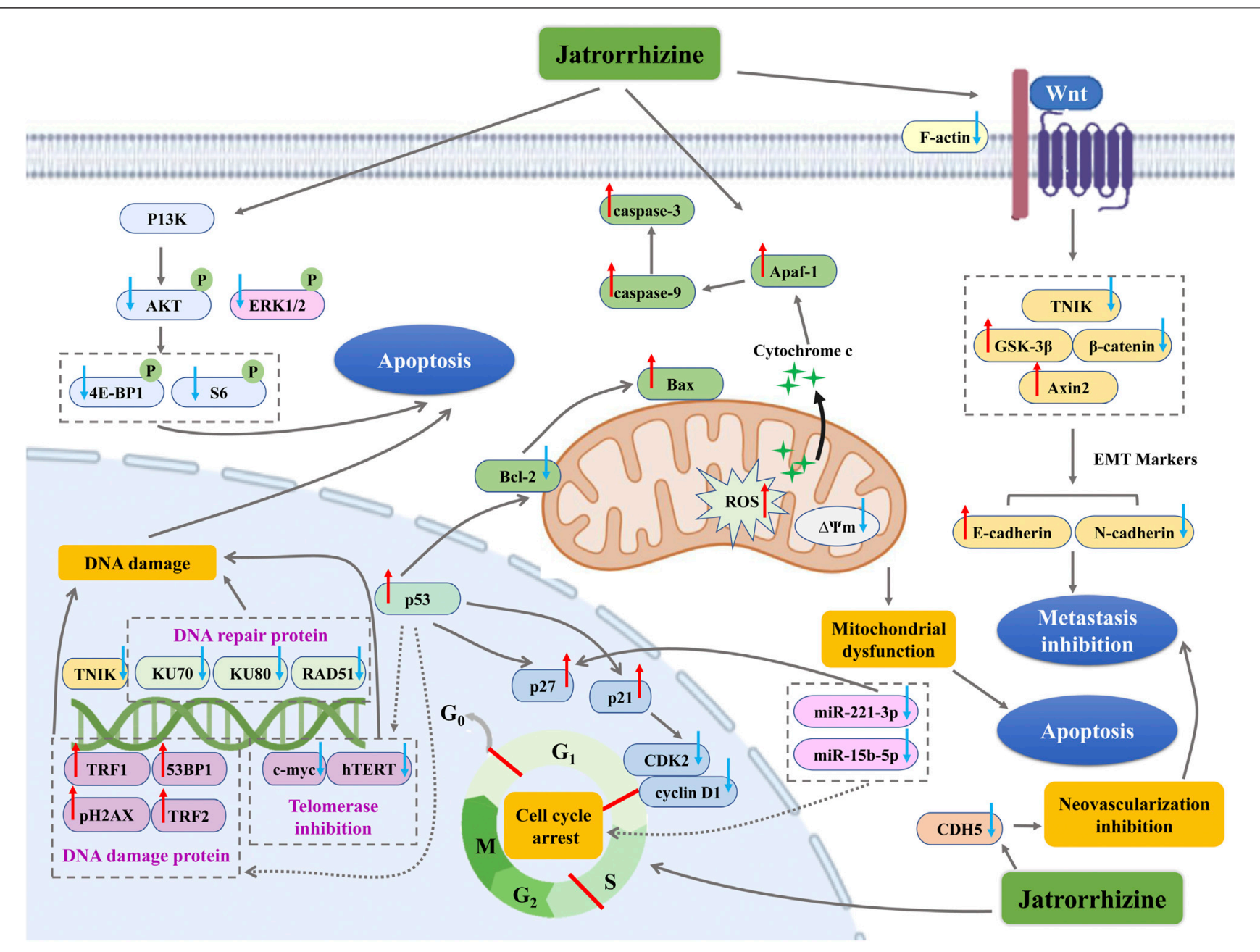

FIGURE 4 | The antitumor mechanism of jatrorrhizine. $\uparrow$ with red color indicate increase/promotion, $\downarrow$ with blue color indicate inhibition/reduction.

\section{Anti-Cancer Activity}

Globally, cancer is one of the major diseases that cause a large number of deaths, and the incidence of cancer is increasing in recent years (Sharma et al., 2019). Inhibition of apoptosis, unlimited proliferation of cancer cells, invasion of normal organs and destruction of normal tissues are the main reasons that cancer threatens human health (Rosell and Karachaliou, 2015; Roy and Saikia, 2016). Over the past decades, development of anti-tumor agents from natural products has been one of the fresh approaches for therapeutic candidate discovery. Jatrorrhizine exhibited anti-cancer activity in various cancer cells (in vitro) and a few in vivo models (Table 3). Its multidirectional mechanisms involve in inhibiting cancer cell proliferation and tumor growth, preventing metastasis, while the important mechanism is promoting apoptosis of cancer cells (Figure 4).

\section{Inhibition of Cell Proliferation}

The rapid and unlimited proliferation of cancer cells is attributed to the loss or gene mutations of critical checkpoint controlling cycling of cell phase (Andrade-Tomaz et al., 2020). As an important process in cancer development, cell cycle modulation is a wellestablished therapeutic schedule. Jatrorrhizine $(5-15 \mu \mathrm{M})$ affected human colorectal carcinoma HCT-116 and HT-29 cells proliferation by blocking cell cycle in $S$ phase and it $(5 \mathrm{mg} / \mathrm{kg})$ could prolong the survival of nude mice xenografted HCT-116 cells (Wang P. et al., 2019). In C8161 human metastatic melanoma cells, jatrorrhizine $(160 \mathrm{mmol} / \mathrm{L})$ inhibited cell proliferation through inducing cell cycle arrest in the G0/G1 phases and upregulating expression of cyclin-dependent kinase (CDK) inhibitors ( $p 21$ and p27) and the tumor suppressor p53 (Liu et al., 2013). The derivative, $\mathrm{Pt}(\mathrm{II})$ complexes with jatrorrhizine blocked cell cycle at G1 phase in human bladder T-24 tumor cells, which was associated with inhibiting the levels of cyclin D1 and CDK2 (Qin et al., 2019a). microRNAs play a prominent role in modulation of cell proliferation by directly targeting cell cycle regulators, such as cyclin, c-myc, p27 and p57 (Yu et al., 2010). Jatrorrhizine $(16.0 \mu \mathrm{M})$ inhibited cell viabilities of HepG2 and HCCLM3 liver cancer cells by down-regulating miR-221-3p and miR-15b-5p expressions (Deng and Wan, 2021). 


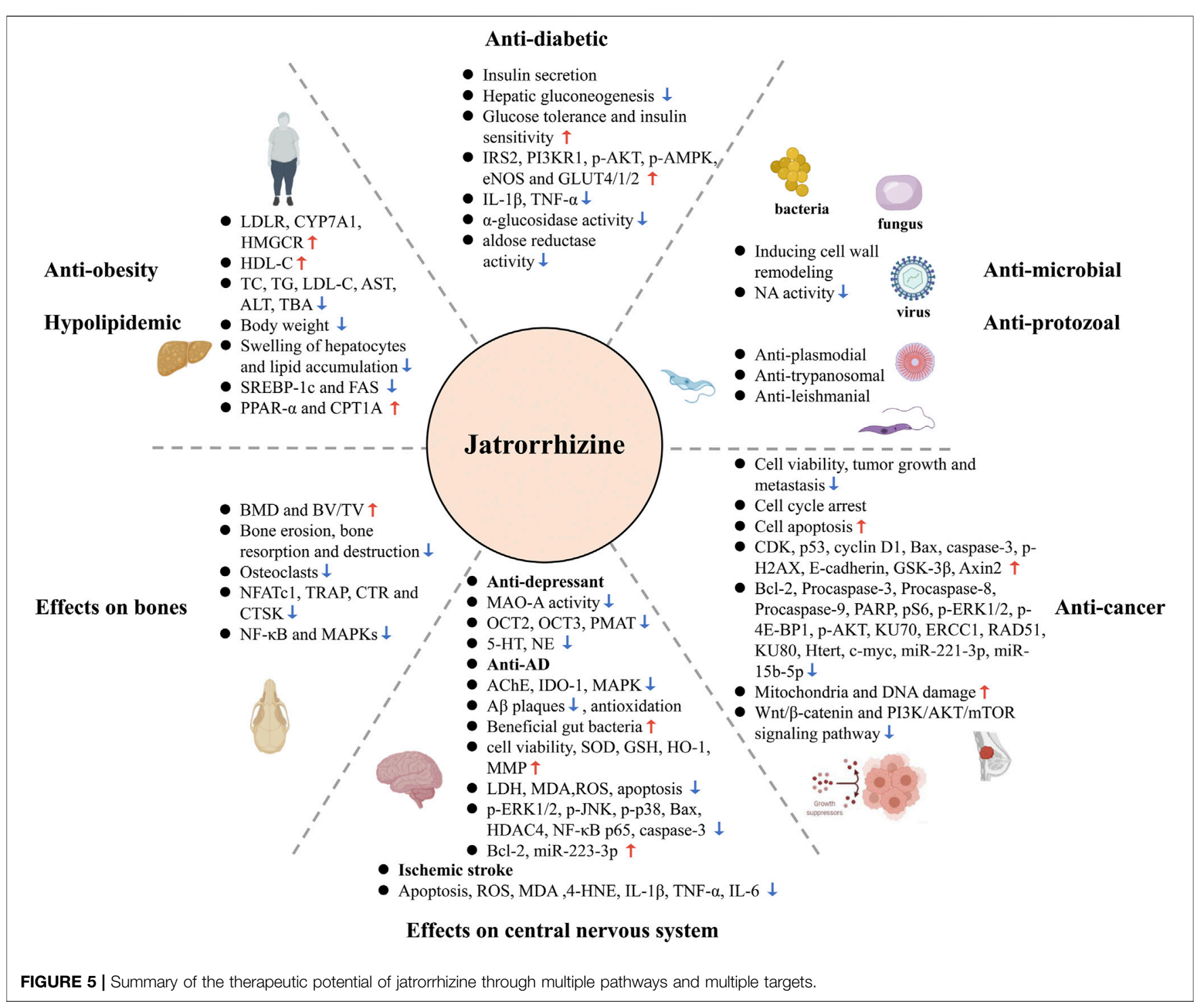

\section{Inhibition of Cancer Cell Metastasis}

Abnormal vascularization and epithelial-mesenchymal transition (EMT) are essential for metastatic spread of cancer cells (Dewaguet et al., 2021). In BALB/C nude mice xenografted metastatic melanoma C8161 cell, jatrorrhizine $(50 \mu \mathrm{g})$ reduced neovascularization of tumor, probably due to its suppression of CDH5 expression, which encodes the vascular endothelial cadherin (Liu et al., 2013). Traf2 and Nck interacting serine protein kinase (TNIK) has been considered as an important activator of Wnt signaling pathway to promote tumor progression and invasion (Yang et al., 2021). MDA-MB-231 human breast cancer cells targeted knockout of TNIK validated that the disruption of TNIK restrained the key proteins expression of $\mathrm{Wnt} / \beta$-catenin signalling and EMT (Sun et al., 2019). Interestingly, jatrorrhizine exhibited good binding affinity and interaction with TNIK. The alkaloid effectively downregulated TNIK, p-TNIK, $\beta$-catenin, F-actin and $\mathrm{N}$-cadherin expression levels, and upregulated GSK-3 $\beta$ and E-cadherin in in vitro (MDA-MB-231 cells and MCF-7 cells) and in vivo models (Orthotopic 4T1 tumour bearing mouse) (Sun et al., 2019). Moreover, jatrorrhizine $(5 \mathrm{mg} / \mathrm{kg}$ ) also reduced tumor volume and weight, and inhibited lung metastasis in nude mice xenografted HCT-116 colorectal carcinoma cells via suppressing Wnt signaling pathway and the process of EMT (Wang P. et al., 2019). Hence, jatrorrhizine is expected to be an anticancer drug targeting TNIK and EMT.

\section{Promotion of Apoptosis}

Apoptosis is considered as a major barrier for the development and progression of cancer (Boudreau et al., 2019). Jatrorrhizine $(10-30 \mu \mathrm{M})$ triggered mitochondrial dysfunction and apoptosis in MDA-MB-231 breast cancer cells. The relevant mechanism was related to disruption of $\Delta \Psi \mathrm{m}$, upregulation of the pro-apoptotic protein Bax, and downregulation of the anti-apoptotic protein $\mathrm{Bcl}-2$, as well 
as decrease of apoptosis-related proteins including Procaspase-3, Procaspase-8, Procas-pase-9 and PARP (Sun et al., 2019). Similarly, jatrorrhizine showed disruptive effect on $\Delta \Psi \mathrm{m}$ and nuclear morphological changes in human colorectal carcinoma HCT-116 and HT-29 cells, indicating mitochondrial dysfunction and early apoptosis (Wang P. et al., 2019). Besides, jatrorrhizine-Platinum(II) complex promoted DNA damage of thyroid cancer SW1736 and BHP7-13 cells via increasing $\mathrm{pH} 2 \mathrm{AX}$ protein (DNA damage protein) and decreasing DNA repair protein KU70, KU80 and RAD51, while activated apoptosis by upregulating ROS and cleaved caspase-3, and downregulating $\mathrm{PI} 3 \mathrm{~K} / \mathrm{AKT} / \mathrm{mTOR}$ pathway (pS6, p-ERK1/2, p-4E-BP1, and p-AKT levels) (Lu et al., 2020). In mice bearing SW1736 tumor xenografts, this derivate suppressed tumor growth and tumor tissues expression of $\mathrm{pH} 2 \mathrm{AX}$, which confirmed its anti-cancer activity in vivo (Lu et al., 2020). The complexes of jatrorrhizine with platinum (Pt1 and $\mathrm{Pt} 2$ ) induced apoptosis in HeLa cancer cells, which was manifested in that these derivates targeted p53 and telomerase and further caused DNA damage via suppression of c-myc and human telomerase reverse transcriptase (hTERT), and activation of 53BP1, pH2AX, TRF1, and TRF2 (Qin et al., 2019b). Consistent with that in HeLa cancer cells, a novel Pt(II) complex as well modulated telomerase related-proteins and DNA damage. It also successfully achieved the induction of apoptosis to decrease $\Delta \Psi \mathrm{m}$ and Bcl-2, increase the release of ROS and cytochrome $c$, and up-regulate caspase-9, caspase- 3 and apoptotic protease activating factor 1 (Apaf-1) (Qin et al., 2019a).

Several studies have illustrated that jatrorrhizine and its derivates exert anti-cancer effect with low systemic toxicity in in vivo models, which inhibited tumor growth and metastasis and prolong the survival time for mice bearing tumor xenografts (Liu et al., 2013; Qin et al., 2019a; Wang P. et al., 2019; Sun et al., 2019). Additionally, the complexes of jatrorrhizine with platinum had good effects in the induction of cisplatin-resistant cancer SK-OV3 cells and could reduce the side effects of anti-tumor drugs such as cisplatin (Qin et al., 2019a; Lu et al., 2020).

On the whole, jatrorrhizine and its derivatives may be a logical agent for tumor therapy. However, in the retrieved studies, the experiments also lacked the information on the selectivity index. More positive controls (anti-cancer drugs for clinical use) are required to further confirm the anticancer effects of jatrorrhizine. We observed that jatrorrhizine inhibited different types of cancer, but in vivo models of different cancer stages including tumorigenesis, development and metastasis were not fully considered. More importantly, elaborative consideration needs to be taken into the validation criteria of the models used. In addition, its clinical efficacy, specific targets and long-term drug safety during cancer treatment are critical issues to be addressed.

\section{Effects on Bones}

Jatrorrhizine inhibited osteolysis in titanium particle-induced murine calvarial osteolytic (C57BL/6 mice). Treatment with the alkaloid $(100 \mathrm{mg} / \mathrm{kg})$ significantly increased bone mineral density (BMD) as well as bone volume/tissue volume (BV/TV), and reduced bone erosion and the number of osteoclasts ( $\mathrm{Li}$ et al., 2018). In bone marrow-derived macrophages, jatrorrhizine inhibited receptor activator of nuclear factor $\kappa-B$ ligand (RANKL)-induced osteoclast formation and bone resorption. Mechanism analysis revealed that these effects were mediated via suppression of MAPK (p38 and ERK) signaling and downregulation of nuclear factor of activated T-cells cytoplasmic 1 (NFATc1) and NFATc1-associated osteoclastic genes including tartrate-resistant acid phosphatase (TRAP), calcitonin receptor (CTR) and cathepsin $\mathrm{K}(C T S K)$ (Li et al., 2018). Also, jatrorrhizine suppressed the activation of NF- $\kappa B$ and MAPK stimulated by TNF- $\alpha$, thereby inhibiting inflammatory responses and bone destruction in collagen-induced arthritis (CIA) rats (Qiu et al., 2018). Bone protection and antiinflammatory effects suggest that jatrorrhizine may be beneficial in reducing infection after orthopaedic titanium implantation. Overall, this natural product may be useful agents for treatment of bone disorders.

\section{Other Pharmacological Activities of Jatrorrhizine Effects on Gastrointestinal Tracts}

Jatrorrhizine at concentrations from 1.0 to $300 \mu \mathrm{M}$ increased the amplitude of spontaneous contractions of gastrointestinal tract smooth muscles isolated from rats in a concentration-dependent manner. Jatrorrhizine $(100 \mu \mathrm{M})$ markedly increased contractile responses of jejunum and ileum longitudinal muscles, antrum circular muscles and smooth muscles in the distal colon. These effects were mediated by activation of acetylcholine receptors (probably M3 receptors) and associated with calcium agonistic effects, including enhancing $\mathrm{Ca}^{2+}$ influx through L-type $\mathrm{Ca}^{2+}$ channel and $\mathrm{Ca}^{2+}$ release via IP3 and ryanodine pathways (Yuan et al., 2011). Moreover, in vivo experiments in rats demonstrated that jatrorrhizine $(0.1,0.3$ and $1 \mathrm{mg} / \mathrm{kg})$ offset postoperative ileusinduced delayed gastric emptying and intestinal transit in a dosedependent manner (Zhang et al., 2012). Hence, jatrorrhizine may be useful for treatment of functional disorders of the gastrointestinal tract.

\section{Hepatoprotective Activity}

Jatrorrhizine is one of the constituents in three traditional Chinese medicine formulae with hepatoprotective activity for treating jaundice, namely Zhi-Zi-Da-Huang-Tang, Yin-ChenHao-Tang and Da-Huang-Xiao-Shi-Tang. The alkaloid decreased the release of $\mathrm{LDH}\left(\mathrm{EC}_{50}=15.7 \pm 3.3 \mu \mathrm{M}\right)$ in a study on t-BHP-injured rat hepatocyte BRL-3A cells. $\mathrm{LDH}$ release is an indicator of liver damage and reduced release is evidence of a hepatoprotective effect against oxidative damage (Wang et al., 2016).

\section{PHARMACOKINETICS OF JATRORRHIZINE}

Pharmacokinetic evaluation of drugs provides increasingly important information for clinical research. The 
TABLE 4 | Pharmacokinetic parameters of jatrorrhizine.

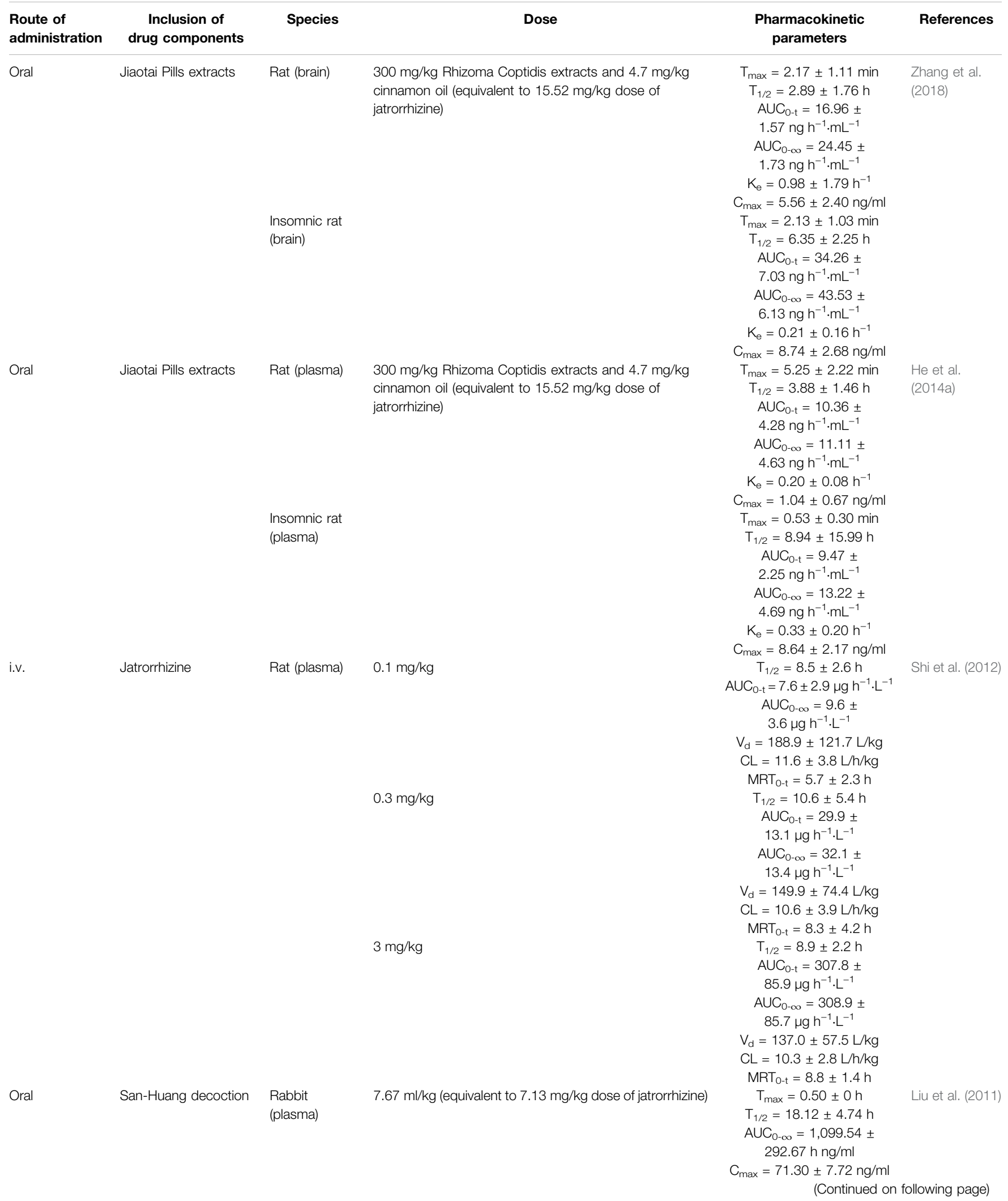


TABLE 4 | (Continued) Pharmacokinetic parameters of jatrorrhizine.

\begin{tabular}{|c|c|c|c|c|c|}
\hline $\begin{array}{l}\text { Route of } \\
\text { administration }\end{array}$ & $\begin{array}{l}\text { Inclusion of } \\
\text { drug components }\end{array}$ & Species & Dose & $\begin{array}{c}\text { Pharmacokinetic } \\
\text { parameters }\end{array}$ & References \\
\hline Oral & $\begin{array}{l}\text { Coptis-evodia powder } \\
(6: 1, g / g)\end{array}$ & Rat (plasma) & $1.086 \mathrm{~g} / \mathrm{kg}$ (equivalent to $14.4 \mathrm{mg} / \mathrm{kg}$ dose of jatrorrhizine) & $\begin{array}{c}\mathrm{T}_{\max }=90 \pm 0 \mathrm{~min} \\
\mathrm{~T}_{1 / 2}=325.3 \pm 8.0 \mathrm{~min} \\
\mathrm{AUC}_{0-\infty}=43,576.9 \pm \\
4,767.8 \mathrm{ng} \mathrm{min} / \mathrm{ml} \\
\mathrm{C}_{\max }=219.9 \pm 12.8 \mathrm{ng} / \mathrm{ml}\end{array}$ & $\begin{array}{l}\text { Deng et al. } \\
\text { (2008) }\end{array}$ \\
\hline Oral & $\begin{array}{l}\text { Shuanghua Baihe } \\
\text { tables powder }\end{array}$ & Rat (plasma) & 800 mg/kg & $\begin{array}{c}\mathrm{T}_{\max }=0.67 \pm 0.23 \mathrm{~h} \\
\mathrm{~T}_{1 / 2}=8.6 \pm 2.61 \mathrm{~h} \\
\mathrm{AUC}_{0-\mathrm{t}}=7.5 \pm 0.87 \mathrm{ng} \mathrm{h} / \mathrm{mL} \\
\mathrm{AUC}_{0-\infty}=8.6 \pm \\
0.80 \mathrm{ng} \mathrm{h} / \mathrm{mL} \\
\mathrm{C}_{\max }=3.12 \pm 0.84 \mathrm{ng} / \mathrm{ml} \\
\mathrm{T}_{\max }=4.2 \pm 0.53 \mathrm{~h} \\
\mathrm{~T}_{1 / 2}=11.1 \pm 2.06 \mathrm{~h} \\
\mathrm{AUC}_{\mathrm{O}-\mathrm{t}}=7.7 \pm 2.02 \mathrm{ng} \mathrm{h} / \mathrm{mL} \\
\mathrm{AUC}_{0-\infty}=11.8 \pm \\
3.06 \mathrm{ng} \mathrm{h} / \mathrm{mL} \\
\mathrm{C}_{\max }=1.53 \pm 0.20 \mathrm{ng} / \mathrm{ml}\end{array}$ & $\begin{array}{l}\text { Zhao et al. } \\
\text { (2018) }\end{array}$ \\
\hline Oral & JinQi Jiangtang tablets & Rat (plasma) & $\begin{array}{l}0.0650 \mathrm{~g} / 200 \mathrm{~g} \\
0.4536 \mathrm{~g} / 200 \mathrm{~g}\end{array}$ & $\begin{array}{c}\mathrm{C}_{\max }=33.35 \pm 5.82 \mu \mathrm{g} / \mathrm{L} \\
\mathrm{AUC}_{\text {O-tn }}=96.58 \pm 21.69 \mathrm{ug} / \\
\mathrm{L} \mathrm{h} \\
\mathrm{MRT}_{\text {O-tn }}=6.14 \pm 0.30 \mathrm{~h} \\
\mathrm{VRT}_{\text {O-tn }}=15.45 \pm 1.26 \mathrm{~h}^{2} \\
\mathrm{C}_{\max }=11.35 \pm 2.48 \mu \mathrm{g} / \mathrm{L} \\
\mathrm{AUC}_{0-\mathrm{tn}}=279.70 \pm \\
83.40 \mathrm{ug} / \mathrm{L} \mathrm{h} \\
\mathrm{MRT}_{\text {O-tn }}=5.08 \pm 0.42 \mathrm{~h} \\
\mathrm{VRT}_{\text {O-tn }}=24.55 \pm 5.42 \mathrm{~h}^{2}\end{array}$ & $\begin{array}{l}\text { Sun et al. } \\
(2018)\end{array}$ \\
\hline Oral & $\begin{array}{l}\text { Coptidis Rhizoma } \\
\text { powder }\end{array}$ & Rat (plasma) & $\begin{array}{l}\text { Rhizoma coptidis powder } 1.08 \mathrm{~g} / \mathrm{kg} \text { and Evodia } \\
\text { rutaecarpa powder } 0.18 \mathrm{~g} / \mathrm{kg}\end{array}$ & $\begin{array}{c}\mathrm{T}_{\max }=0.75 \pm 0.11 \mathrm{~h} \\
\mathrm{~T}_{1 / 2}=7.1 \pm 6.4 \mathrm{~h} \\
\mathrm{AUC}_{0-\mathrm{t}}=123.1 \pm 31.1 \mu \mathrm{g} / \mathrm{L} \cdot \mathrm{h} \\
\mathrm{AUC}_{0-\infty}=128.9 \pm \\
37.4 \mu \mathrm{g} / \mathrm{L} \cdot \mathrm{h} \\
\mathrm{MRT}_{\mathrm{O}-\mathrm{t}}=3.5 \pm 0.8 \mathrm{~h} \\
\mathrm{MRT}_{0-\infty}=4.9 \pm 3.8 \mathrm{~h} \\
\mathrm{C}_{\max }=82.09 \pm 17.44 \mu \mathrm{g} / \mathrm{L} \\
\mathrm{T}_{\max }=1.50 \pm 0.89 \mathrm{~h} \\
\mathrm{~T}_{1 / 2}=8.0 \pm 3.7 \mathrm{~h} \\
\mathrm{AUC}_{0-\mathrm{t}}=107.9 \pm 50.8 \mu \mathrm{g} / \mathrm{L} \cdot \mathrm{h} \\
\mathrm{AUC}_{0-\infty}=113.8 \pm \\
48.1 \mu \mathrm{g} / \mathrm{L} \cdot \mathrm{h} \\
\mathrm{MRT}_{0-\mathrm{t}}=4.3 \pm 0.9 \mathrm{~h} \\
\mathrm{MRT}_{0-\infty}=5.9 \pm 3.0 \mathrm{~h} \\
\mathrm{C}_{\max }=39.63 \pm 13.35 \mu \mathrm{g} / \mathrm{L}\end{array}$ & $\begin{array}{l}\text { Yan et al. } \\
(2012)\end{array}$ \\
\hline
\end{tabular}

$T_{\text {max: }}$ the time of maximum plasma concentration; $T_{1 / 2}$ : the elimination half-life; AUC: area under the concentration-time curve; $C_{\text {max: }}$ maximum plasma concentration; $K_{e}:$ eliminate rate constant; $V_{d}$ : apparent volume of distribution; $C L$ : clearance; MRT: mean residence time; VRT: the variance of residence time.

pharmacokinetic profile of jatrorrhizine after oral or intravenous administration was assessed in rats and rabbits using liquid chromatography-tandem mass spectrometry (LC-MS/MS), LCMS/MS combined with brain micro-dialysis, ultra-high performance liquid chromatography-mass spectrometry (UPLC-MS/MS), UPLC-orbitrap mass spectrometry and liquid chromatography quadrupole time-of-flight mass spectrometry (LC-qTOF-MS) (Deng et al., 2008; Liu et al., 2011; Shi et al., 2012; He W. et al., 2014; Zhang et al., 2018). The pharmacokinetic parameters of these studies are shown in Table 4.

Cui et al. (2015) reported permeability and absorption of jatrorrhizine in rats after oral administration. An apparent permeability coefficient of jatrorrhizine $\left(0.23-0.36 \times 10^{-6} \mathrm{~cm} \mathrm{~s}^{-1}\right)$ indicated limited ability to cross cell membranes. P-glycoprotein (P-gp) efflux had a significant effect on the absorption of this compound, which may explain its poor bioavailability. Intestinal perfusion experiments confirmed absorption into the rat jejunum $(8.98 \pm 2.43 \%)$ and ileum $(7.54 \pm 1.45 \%)$ (Cui et al., 2015). Jiaotai Pill extracts containing jatrorrhizine $(15.52 \mathrm{mg} / \mathrm{kg})$ was administered orally to rats and the pharmacokinetic parameters in rat brain were assessed using LC-MS/MS. The half-life of terminal elimination phase $\left(\mathrm{T}_{1 / 2}\right)$, AUC ${ }_{(0-\mathrm{t})}$, $\mathrm{AUC}{ }_{(0-\infty)}$, and $\mathrm{C}_{\max }$ in insomnic rats were increased compared with normal controls (Zhang et al., 2018). Thus, the absorption and bioavailability of jatrorrhizine may increase under pathological conditions. A study on plasma pharmacokinetics reported similar results (He W. et al., 2014). 
Rat plasma jatrorrhizine concentrations showed a biphasic decline, dose-independent clearance $\left(\mathrm{C}_{\mathrm{L}}\right)$ and $\mathrm{T}_{1 / 2}$, and dose dependent AUC $(0-\infty)$ after intravenous administration $(0.1 \mathrm{mg} / \mathrm{kg}$ to $3 \mathrm{mg} / \mathrm{kg})$. Large distribution volumes $\left(\mathrm{V}_{\mathrm{d}}\right)$ indicated that jatrorrhizine might be distributed across tissues (Shi et al., 2012). Also, three peaks were observed in both individual and mean plasma-concentration curves of jatrorrhizine in rats after oral gavage with Coptis-Evodia powder $(1.086 \mathrm{~g} / \mathrm{kg})$. This finding may be explained by distribution, reabsorption and enterohepatic circulation (Deng et al., 2008). In addition, absorption and elimination of jatrorrhizine are also influenced by compounds and other herbs coexisting with it, such as Astragali Radix, Lonicerae Japonicae Flos and Fructus Evodiae (Yan et al., 2012; Sun et al., 2018; Zhao et al., 2018). It is required to explore and confirm the compound-compound and compound-herb interaction mechanism in the further research.

Biotransformation of jatrorrhizine was similar among liver microsomes from rats, rhesus monkeys and humans. $\mathrm{C}_{20} \mathrm{H}_{20} \mathrm{O}_{7} \mathrm{~N}$ was the major metabolite in these species (Li et al., 2015). Seventeen metabolites in rat urine, thirteen metabolites in rat faeces (including eight phase I metabolites and five phase II metabolites) and eleven metabolites in rat plasma (including six phase I metabolites and five phase II metabolites) were detected after oral administration of jatrorrhizine $(34 \mathrm{mg} / \mathrm{kg})$ to healthy rats. Further, seventeen and nine metabolites were identified after incubating jatrorrhizine with rat intestinal flora and liver microsomes, respectively (Zhang et al., 2008). Also, jatrorrhizine metabolism exhibited high consistency between human and zebrafish (Li et al., 2015). Additionally, seven phase I metabolites of jatrorrhizine after demethylation, dehydrogenation and dihydroxylation, and eleven phase II metabolites including glucuronide and methyl conjugates were detected in rat urine (Han et al., 2006). Cytochrome P450 and UDP-glucuronosyltransferase enzymes are responsible for the metabolism of jatrorrhizine in human liver microsomes, including CYP1A2 and multiple UGT1A isoforms (UGT1A1, UGT1A3, UGT1A7, UGT1A8, UGT1A9 and UGT1A10) (Zhou et al., 2013). CYP3A1/2 and CYP2D2 were also involved in demethylation of jatrorrhizine and UGT1A1 and UGT 1A3 were associated with glucuronidation in rat liver microsomes (Shi et al., 2012).

\section{TOXICITY OF JATRORRHIZINE}

Toxicity and safety are critical for the assessment of clinical applications of natural products (Li et al., 2021). Jatrorrhizine is a bioactive metabolite in some commonly used medicinal plants and has been used for centuries in traditional medicine. However, analyses of the composition of traditional medicines and modern pharmacology research indicate that some natural products may produce adverse effects or even overt toxicity under certain conditions despite their beneficial pharmacological properties. Jatrorrhizine exhibited anti-cancer activity on SW480 cells (human colon cancer) and HepG2 cells (hepatocellular carcinoma) as discussed above. However, it also showed cytotoxicity against these cancer cells the at the concentrations of $200 \mu \mathrm{g} / \mathrm{ml}$ and $100 \mu \mathrm{M}$, respectively (Chen et al., 2012; Singh et al., 2016). Slight cytotoxicity was also reported in normal MCF10A normal breast eptithelial cells in vitro $(100 \mu \mathrm{M})$ (Sun et al., 2019). However, jatrorrhizine did not cause cytotoxicity to MCF-7 cells at the concentration below $10 \mu \mathrm{M}$ (Lo et al., 2017). Additionally, Sun et al. (2019) reported that gross necropsy did not show signs of toxicity in the jatrorrhizine-treated $(2.5$ and $5 \mathrm{mg} / \mathrm{kg}$ ) 4T1tumourbearing mice (Sun et al., 2019). Also, there was no significant changes in body weight and serum ALT and AST levels in jatrorrhizine (25 and $100 \mathrm{mg} / \mathrm{kg}$ )-treated Ti particle-induced mice, as compared with the untreated and control groups (Li et al., 2018). The alkaloid was also non-cytotoxic to rheumatoid arthritis-derived fibroblast-like synoviocyte MH7A cells, and no damage to liver function was observed in CIA rats at administered doses of 20 and $50 \mathrm{mg} / \mathrm{kg}$ (Qiu et al., 2018).

An acute $\mathrm{LD}_{50}$ value for jatrorrhizine was about $5,500 \mathrm{mg} / \mathrm{kg}$ in Kunming mice, and significantly higher than that of the related alkaloid, berberine $(763 \mathrm{mg} / \mathrm{kg})$. No influences on body weight and organ weight were observed in rats in a sub-chronic study, and no abnormalities in urinalysis and haematological parameters, gross necropsy or histology were reported after administration of jatrorrhizine $(70.05 \mathrm{mg} / \mathrm{kg}$ day) over 90 days (Wu et al., 2014). Few indications of adverse effects of jatrorrhizine are available, but we should explore mechanisms for any toxicity observed in particular clinical circumstances.

\section{CONCLUSION AND FUTURE PERSPECTIVES}

Jatrorrhizine is encountered in a variety of traditional medicinal plants. This bioactive metabolite possesses numerous pharmacological properties via modulation of multiple signaling pathways and targets (Figure 5), such as AR, NA, MAO-A, OCT, PMAT, AChE, IDO-1, TNIK, and Wnt/ $\beta$-catenin, MAPK, PI3K/ $\mathrm{AKT} / \mathrm{mTOR}, \mathrm{NF}-\kappa \mathrm{B}, \mathrm{PPAR}$, and insulin signaling pathway. This review summarizes molecular mechanisms for possible use in the treatment of diseases, discusses pharmacokinetic parameters and evaluates toxicity and safety. However, some issues still need clarification in the future studies.

\section{Curative Mechanisms of Jatrorrhizine and Clinical Validity Confirmation}

We recognise a potential for jatrorrhizine to be a therapeutic ingredient in medications, reflecting its impacts on multiple pathways and targets. However, its specific mechanisms of action against various diseases are not fully understood. Clarification the molecular targets of jatrorrhizine is conducive to a more scientific understanding and development of this natural metabolite. Currently, this natural metabolite is rarely alone used clinically to treat specific diseases even though it is the main active substance in some medicinal materials and extracts and has a role in the treatment of diabetes, gastrointestinal diseases, and Alzheimer's disease in traditional medicine. Proper positive controls are necessary for future work to ensure the reproducibility and data quality for comparisons of therapeutic effects on various diseases and different disease stages. Sufficient evidence is available to support the detailed assessment of curative mechanisms of jatrorrhizine, structure-activity studies and clinical trials in humans. Such work 
should be approached systematically to fully explore the clinical utility of the alkaloid.

Jatrorrhizine is widely reported to exhibit pro-apoptotic effects in multiple cancer cells. However, it displays a protective role in $\mathrm{AD}$ and ischaemic stroke via reducing apoptosis. Mechanisms underlying these disparate effects require elucidation to understand actions on apoptosis in neuroprotection and cancer therapy, and subsequently improve targeting and specificity of jatrorrhizine through structural modification and dosage form optimization (e.g., as nanoparticles and liposome).

\section{Application Prospect of Jatrorrhizine in the Treatment of Metabolic Disorders}

Long-term metabolic disorders and hyperglycemia remain a challenge in medical practice. These conditions cause a series of complications, such as cardiovascular disease, retinopathy, neuropathy and nephropathy. Current therapeutics for metabolic diseases require a multi-drug regimen. However, major problems of this therapeutic method are poor patient compliance, side effects and drug-drug interactions (Lillich et al., 2021). Multi-target ligands and drugs have been proposed as promising approaches to developing therapies for complex diseases (González-Álvarez et al., 2021). Jatrorrhizine is a multi-purpose natural metabolite that affects multiple targets. The alkaloid effectively modulates glucose and lipid metabolism and exhibits anti-inflammatory, anti-oxidant and anti-cancer effects. It is also a safe and controllable natural product. Therefore, the use of jatrorrhizine, alone or as a supplement to other nutraceuticals, is a potential strategy to address multiple pathways and targets to delay metabolic disorders and affect the long-term treatment of related complications.

\section{Comprehensive Investigations of Toxicity Mechanisms}

We found that jatrorrhizine exerts cytotoxic effects under specific circumstances in vitro. High dose and long-term administration may lead to cytotoxicity in a few cancer cell lines, such as colon cancer and hepatocellular carcinoma cells and normal breast epithelial cells. However, there was no studies that report target-organ toxicity of jatrorrhizine in different disease models. The existing in vivo studies indicated that jatrorrhizine is non-cytotoxic and has no influence on liver function or other tissues. Therefore, further comprehensive investigation for mechanisms of toxicity is

\section{REFERENCES}

Abdykerimova, S., Sakipova, Z., Nakonieczna, S., Koch, W., Biernasiuk, A., Grabarska, A., et al. (2020). Superior Antioxidant Capacity of Berberis Iliensis-HPLC-Q-TOF-MS Based Phytochemical Studies and Spectrophotometric Determinations. Antioxidants (Basel) 9 (6), 504. doi:10.3390/antiox9060504

Achenbach, H., and Hemrich, H. (1991). Clerodane-Type Diterpenes and Other Constituents of Penianthus Zenkeri. Phytochemistry 30 (6), 1957-1962. doi:10.1016/0031-9422(91)85047-4 needed and further exploration of whether jatrorrhizine has target organ toxicity under special circumstances in vivo is of significance. Such studies will serve as a basis to further evaluate the safety of jatrorrhizine in the treatment of different diseases and for chronic administration.

\section{Interaction Mechanism of Jatrorrhizine With Other Compounds and Development of Derivatives}

Jatrorrhizine displays low permeability and poor bioavailability. Interestingly, jatrorrhizine may interact with other constituents and thereby alter its absorption and elimination. Additionally, different salt forms of quaternary ammonium compounds show varying physicochemical properties. Thus, salts of jatrorrhizine might exhibit different pharmacokinetic properties in vivo (Neef et al., 1984; Cui et al., 2019). Berberine, an alkaloid similar in chemical structure to jatrorrhizine, displays better bioavailability of its organic acid salts (fumarate, malate, succinate and citrate) than inorganic acid salts (hydrochloride) (Cui et al., 2019). The hydrochloride salt is commonly used in clinical practice and pharmacological research. However, almost no reports on the pharmacokinetics of other salts and comparative studies of different salt forms are available for jatrorrhizine. Therefore, the investigation of interactions between jatrorrhizine and other compounds and the effects of different salt forms on pharmacokinetics is crucial. The improvement of the bioavailability of jatrorrhizine and development of jatrorrhizine derivatives with high bioavailability and low toxicity also needs to be explored.

\section{AUTHOR CONTRIBUTIONS}

FZ and YM designed this work of review. FZ and YC collected the literatures related to jatrorrhizine. FZ, YC, JC, YL, and $\mathrm{HL}$ analyzed literatures and summarized results. FZ wrote the manuscript. HL, YM revised the manuscript.

\section{FUNDING}

This work was supported by Sichuan Science and Technology Support Program (2020YFN0152), and National Wild Plant Germplasm Resource Center for South China Botanic Garden, CAS (ZWGX 1905).

Alamzeb, M., Khan, M. R., Mamoon-Ur-Rashid, Ali, S., and Khan, A. A. (2015). A New Isoquinoline Alkaloid with Anti-Microbial Properties from Berberis Jaeschkeana Schneid. Var. Jaeschkeana. Nat. Prod. Res. 29 (8), 692-697. doi:10.1080/14786419.2014.981187

Al-Howiriny, T. A., Zemaitis, M. A., Lin, F. T., Beal, J. L., and Schiff, P. L. (2002). Alkaloids of Thalictrum Angustifolium. J. Herb. Pharmacother. 2 (2), 1-10. doi:10.1080/j157v02n02_01

Ali, S., Igoli, J., Clements, C., Alamzeb, M., Shah, S. Q., Ferro, V. A., et al. (2013). Anti-diabetic and Antimicrobial Activities of Fractions and Compounds Isolated from Berberis Brevissima Jafri and Berberis Parkeriana Schneid. Bangl. J. Pharmacol. 8 (3), 336-342. doi:10.3329/bjp.v8i3.13888 
Andrade-Tomaz, M., de Souza, I., Rocha, C. R. R., and Gomes, L. R. (2020). The Role of Chaperone-Mediated Autophagy in Cell Cycle Control and its Implications in Cancer. Cells 9 (9), 2140. doi:10.3390/cells9092140

Bacq, A., Balasse, L., Biala, G., Guiard, B., Gardier, A. M., Schinkel, A., et al. (2012). Organic Cation Transporter 2 Controls Brain Norepinephrine and Serotonin Clearance and Antidepressant Response. Mol. Psychiatry 17 (9), 926-939. doi:10.1038/mp.2011.87

Bajpai, V., Singh, A., Chandra, P., Negi, M. P., Kumar, N., and Kumar, B. (2016). Analysis of Phytochemical Variations in Dioecious Tinospora Cordifolia Stems Using HPLC/QTOF MS/MS and UPLC/QqQLIT -MS/MS. Phytochem. Anal. 27 (2), 92-99. doi:10.1002/pca.2601

Basera, I. A., Girme, A., Bhatt, V. P., and Shah, M. B. (2021). A Validated HighPerformance Thin-Layer Chromatography Method for the Simultaneous Estimation of Berberine, Berbamine, Palmatine, Magnoflorine and Jatrorrhizine from Berberis Aristata. Jpc-j. Planar Chromat. 34, 147-155. doi:10.1007/s00764-021-00094-9

Boudreau, M. W., Peh, J., and Hergenrother, P. J. (2019). Procaspase-3 Overexpression in Cancer: a Paradoxical Observation with Therapeutic Potential. ACS Chem. Biol. 14 (11), 2335-2348. doi:10.1021/ acschembio.9b00338

Chao, J., Lu, T. C., Liao, J. W., Huang, T. H., Lee, M. S., Cheng, H. Y., et al. (2009). Analgesic and Anti-inflammatory Activities of Ethanol Root Extract of Mahonia Oiwakensis in Mice. J. Ethnopharmacol. 125 (2), 297-303. doi:10.1016/j.jep.2009.06.024

Chen, H. Y., Ye, X. L., Cui, X. L., He, K., Jin, Y. N., Chen, Z., et al. (2012). Cytotoxicity and Antihyperglycemic Effect of Minor Constituents from Rhizoma Coptis in HepG2 Cells. Fitoterapia 83 (1), 67-73. doi:10.1016/ j.fitote.2011.09.014

Chen, H., Fan, G., and He, Y. (2017). Species Evolution and Quality Evaluation of Four Coptis Herbal Medicinal Materials in Southwest China. 3 Biotech. 7 (1), 62. doi:10.1007/s13205-017-0679-8

Constantine, G. H., Jr, Vitek, M. R., Sheth, K., Catalfomo, P., and Sciuchetti, L. A. (1966). Chromatographic Study of the Alkaloids of Aquilegia Formosa. J. Pharm. Sci. 55 (9), 982-984. doi:10.1002/jps.2600550926

Cui, H. M., Zhang, Q. Y., Wang, J. L., Chen, J. L., Zhang, Y. L., and Tong, X. L. (2015). Poor Permeability and Absorption Affect the Activity of Four Alkaloids from Coptis. Mol. Med. Rep. 12 (5), 7160-7168. doi:10.3892/mmr.2015.4288

Cui, H., Hu, Y., Li, J., Yuan, K., and Guo, Y. (2019). Preparation and Evaluation of Antidiabetic Agents of Berberine Organic Acid Salts for Enhancing the Bioavailability. Molecules 24 (1), 103. doi:10.3390/molecules24010103

Da-Cunha, E. V., Fechinei, I. M., Guedes, D. N., Barbosa-Filho, J. M., and Da Silva, M. S. (2005). Protoberberine Alkaloids. Alkaloids Chem. Biol. 62, 1-75. doi:10.1016/s1099-4831(05)62001-9

Dary, C., Bun, S. S., Herbette, G., Mabrouki, F., Bun, H., Kim, S., et al. (2017). Chemical Profiling of the Tuber of Stephania Cambodica Gagnep. (Menispermaceae) and Analytical Control by UHPLC-DAD. Nat. Prod. Res. 31 (7), 802-809. doi:10.1080/14786419.2016.1247077

DeFronzo, R. A., Ferrannini, E., Groop, L., Henry, R. R., Herman, W. H., Holst, J. J., et al. (2015). Type 2 Diabetes Mellitus. Nat. Rev. Dis. Primers 1 (1), 15019-15022. doi:10.1038/nrdp.2015.19

Deng, B., and Wan, M. (2021). Jatrorrhizine Inhibits Liver Cancer Cell Growth by Targeting the Expressions of miR-221-3p and miR-15b-5p. Trop. J. Pharm. Res. 20 (8), 1573-1578. doi:10.4314/tjpr.v20i8.4

Deng, Y., Liao, Q., Li, S., Bi, K., Pan, B., and Xie, Z. (2008). Simultaneous Determination of Berberine, Palmatine and Jatrorrhizine by Liquid Chromatography-Tandem Mass Spectrometry in Rat Plasma and its Application in a Pharmacokinetic Study after Oral Administration of Coptis-Evodia Herb Couple. J. Chromatogr. B Analyt Technol. Biomed. Life Sci. 863 (2), 195-205. doi:10.1016/j.jchromb.2007.12.028

Desgrouas, C., Taudon, N., Bun, S. S., Baghdikian, B., Bory, S., Parzy, D., et al. (2014). Ethnobotany, Phytochemistry and Pharmacology of Stephania Rotunda Lour. J. Ethnopharmacol. 154 (3), 537-563. doi:10.1016/j.jep.2014.04.024

Dewaguet, J., Copin, M. C., Duhamel, A., Faivre, J. B., Deken, V., Sedlmair, M., et al. (2021). Dual-Energy CT Perfusion of Invasive Tumor Front in Non-Small Cell Lung Cancers. Radiology, 210600. doi:10.1148/radiol.2021210600

Du, W., Jin, L., Li, L., Wang, W., Zeng, S., Jiang, H., et al. (2018). Development and Validation of a HPLC-ESI-MS/MS Method for Simultaneous Quantification of Fourteen Alkaloids in Mouse Plasma after Oral Administration of the Extract of
Corydalis Yanhusuo Tuber: Application to Pharmacokinetic Study. Molecules 23 (4), 714. doi:10.3390/molecules23040714

Duan, W., and Chen, X. (2021). Jatrorrhizine Can Improve Nerve Cell Injury Induced by A $\beta$ 25-35, Acting through miR-223-3p/HDAC4 axis. Am. J. Transl. Res. 13 (5), 4644-4655.

Fechine, I. M., Lima, M. A., Navarro, V. R., Da Cunha, E. V. L., Silva, M. S., Barbosa-Filho, J. M., et al. (2002). Alcalóides de Duguetia trunciflora Maas (Annonaceae). Rev. Bras. Farmacogn. 12, 17-19. doi:10.1590/s0102695x2002000300009

Feng, T., Du, H., Chen, H., Xiao, Q., He, Y., and Fan, G. (2018). Comparative Analysis of Genetic and Chemical Differences between Four Berberis Herbs Based on Molecular Phylogenetic and HPLC Methods. Biol. Pharm. Bull. 41 (12), 1870-1873. doi:10.1248/bpb.b18-00327

Furuya, T., Yoshikawa, T., and Kiyohara, H. (1983). Alkaloid Production in Cultured Cells of Dioscoreophyllum Cumminsii. Phytochemistry 22 (7), 1671-1673. doi:10.1016/0031-9422(83)80108-3

González-Álvarez, H., Bravo-Jiménez, A., Martínez-Arellanes, M., GamboaOsorio, G. O., Chávez-Gutiérrez, E., González-Hernández, L. A., et al. (2021). In Silico-Based Design and In Vivo Evaluation of an Anthranilic Acid Derivative as a Multitarget Drug in a Diet-Induced Metabolic Syndrome Model. Pharmaceuticals 14 (9), 914. doi:10.3390/ph14090914

Gurib-Fakim, A. (2006). Medicinal Plants: Traditions of Yesterday and Drugs of Tomorrow. Mol. Aspects Med. 27 (1), 1-93. doi:10.1016/j.mam.2005.07.008

Hagel, J. M., and Facchini, P. J. (2010). Dioxygenases Catalyze the O-Demethylation Steps of Morphine Biosynthesis in Opium Poppy. Nat. Chem. Biol. 6 (4), 273-275. doi:10.1038/nchembio.317

Han, F. M., Zhu, M. M., Chen, H. X., and Chen, Y. (2006). Liquid Chromatography-Tandem Electrospray Ionization Ion Trap Mass Spectrometric Assay for the Metabolites of Jatrorrhizine in Rat Urine. Yao Xue Xue Bao 41 (9), 846-851. doi:10.16438/j.0513-4870.2006.09.009

He, J. M., and Mu, Q. (2015). The Medicinal Uses of the Genus Mahonia in Traditional Chinese Medicine: An Ethnopharmacological, Phytochemical and Pharmacological Review. J. Ethnopharmacol. 175, 668-683. doi:10.1016/ j.jep.2015.09.013

He, W., Liu, G., Cai, H., Sun, X., Hou, W., Zhang, P., et al. (2014a). Integrated Pharmacokinetics of Five Protoberberine-type Alkaloids in normal and Insomnic Rats after Single and Multiple Oral Administration of Jiao-TaiWan. J. Ethnopharmacol. 154 (3), 635-644. doi:10.1016/j.jep.2014.04.040

He, Y., Hou, P., Fan, G., Arain, S., and Peng, C. (2014b). Comprehensive Analyses of Molecular Phylogeny and Main Alkaloids for Coptis (Ranunculaceae) Species Identification. Biochem. Syst. Ecol. 56, 88-94. doi:10.1016/j.bse.2014.05.002

He, K., Kou, S., Zou, Z., Hu, Y., Feng, M., Han, B., et al. (2016). Hypolipidemic Effects of Alkaloids from Rhizoma Coptidis in Diet-Induced Hyperlipidemic Hamsters. Planta Med. 82 (8), 690-697. doi:10.1055/s-0035-1568261

He, S. M., Liang, Y. L., Cong, K., Chen, G., Zhao, X., Zhao, Q. M., et al. (2018). Identification and Characterization of Genes Involved in Benzylisoquinoline Alkaloid Biosynthesis in Coptis Species. Front. Plant Sci. 9, 731. doi:10.3389/ fpls.2018.00731

Hussain, R. A., Kim, J., Beecher, C. W., and Douglas Kinghorn, A. (1989). Unambiguous Carbon-13 NMR Assignments of Some Biologically Active Photoberberine Alkaloids. Heterocycles 29 (12), 2257-2260.

Ikuta, A., Syōno, K., and Furuya, T. (1975). Alkaloids in Plants Regenerated from Coptis Callus Cultures. Phytochemistry 14 (5-6), 1209-1210. doi:10.1016/s00319422(00)98596-0

Iwasa, K., Takahashi, T., Nishiyama, Y., Moriyasu, M., Sugiura, M., Takeuchi, A., et al. (2008). Online Structural Elucidation of Alkaloids and Other Constituents in Crude Extracts and Cultured Cells of Nandina Domestica by Combination of LC-MS/MS, LC-NMR, and LC-CD Analyses. J. Nat. Prod. 71 (8), 1376-1385. doi:10.1021/np8001496

Jiang, W., Duan, W. B., Li, S., Shen, X. Y., Zhou, Y., Luo, T., et al. (2015). Jatrorrhizine Protects against Okadaic Acid Induced Oxidative Toxicity through Inhibiting the Mitogen-Activated Protein Kinases Pathways in HT22 Hippocampal Neurons. CNS Neurol. Disord. Drug Targets 14 (10), 1334-1342. doi:10.2174/1871527314666150821104455

Jiang, X., Zhang, N., Xiong, N., Liu, Y., Cao, J., and Qiu, S. (2017). Synthesis and Biological Evaluation of Novel Jatrorrhizine Derivatives with Amino Groups Linked at the 3-position as Inhibitors of Acetylcholinesterase. J. Chem-ny 2017, 3261520. doi: $10.1155 / 2017 / 3261520$ 
Karri, S., Sharma, S., Hatware, K., and Patil, K. (2019). Natural Anti-obesity Agents and Their Therapeutic Role in Management of Obesity: A Future Trend Perspective. Biomed. Pharmacother. 110, 224-238. doi:10.1016/ j.biopha.2018.11.076

Kim, J. H., Ryu, Y. B., Lee, W. S., and Kim, Y. H. (2014). Neuraminidase Inhibitory Activities of Quaternary Isoquinoline Alkaloids from Corydalis Turtschaninovii Rhizome. Bioorg. Med. Chem. 22 (21), 6047-6052. doi:10.1016/ j.bmc.2014.09.004

Kong, L. D., Cheng, C. H., and Tan, R. X. (2001). Monoamine Oxidase Inhibitors from Rhizoma of Coptis Chinensis. Planta Med. 67 (1), 74-76. doi:10.1055/s2001-10874

Kukula-Koch, W. (2017). The Elevation of LC-ESI-Q-TOF-MS Response in the Analysis of Isoquinoline Alkaloids from Some Papaveraceae and Berberidaceae Representatives. J. Anal. Methods Chem. 2017, 8384107. doi:10.1155/2017/ 8384107

Le, P. M., McCooeye, M., and Windust, A. (2014). Application of UPLC-QTOFMS in MS(E) Mode for the Rapid and Precise Identification of Alkaloids in Goldenseal (Hydrastis canadensis). Anal. Bioanal. Chem. 406 (6), 1739-1749. doi:10.1007/s00216-013-7558-x

Li, Y., Wang, H., Si, N., Ren, W., Han, L., Xin, S., et al. (2015). Metabolic Profiling Analysis of Berberine, Palmatine, Jatrorrhizine, Coptisine and Epiberberine in Zebrafish by Ultra-High Performance Liquid Chromatography Coupled with LTQ Orbitrap Mass Spectrometer. Xenobiotica 45 (4), 302-311. doi:10.3109/ 00498254.2014.979270

Li, L., Sun, S., Weng, Y., Song, F., Zhou, S., Bai, M., et al. (2016). Interaction of Six Protoberberine Alkaloids with Human Organic Cation Transporters 1, 2 and 3. Xenobiotica 46 (2), 175-183. doi:10.3109/00498254.2015.1056283

Li, H., Wang, J., Sun, Q., Chen, G., Sun, S., Ma, X., et al. (2018). Jatrorrhizine Hydrochloride Suppresses RANKL-Induced Osteoclastogenesis and Protects against Wear Particle-Induced Osteolysis. Int. J. Mol. Sci. 19 (11), 3698. doi:10.3390/ijms19113698

Li, Q., Zhao, C., Zhang, Y., Du, H., Xu, T., Xu, X., et al. (2020). 1H NMR-Based Metabolomics Coupled with Molecular Docking Reveal the Anti-Diabetic Effects and Potential Active Components of Berberis Vernae on Type 2 Diabetic Rats. Front. Pharmacol. 11, 932. doi:10.3389/fphar.2020.00932

Li, X., Zhang, C., Ma, W., Xie, X., and Huang, Q. (2021). Oridonin: A Review of its Pharmacology, Pharmacokinetics and Toxicity. Front. Pharmacol. 12, 1642. doi:10.3389/fphar.2021.645824

Lillich, F. F., Imig, J. D., and Proschak, E. (2021). Multi-Target Approaches in Metabolic Syndrome. Front. Pharmacol. 11, 554961. doi:10.3389/ fphar.2020.554961

Lin, Y., Guo, H. C., Kuang, Y., Shang, Z. P., Li, B., Chen, K., et al. (2020). AChE Inhibitory Alkaloids from Coptis Chinensis. Fitoterapia 141, 104464. doi:10.1016/j.fitote.2019.104464

Liu, F., Li, Z., Shi, X., and Zhong, M. (2011). Determination of Berberine, Palmatine and Jatrorrhizine in Rabbit Plasma by Liquid Chromatography-Electrospray Ionization-Mass Spectrometry. J. Pharm. Biomed. Anal. 56 (5), 1006-1015. doi:10.1016/j.jpba.2011.08.001

Liu, R., Cao, Z., Pan, Y., Zhang, G., Yang, P., Guo, P., et al. (2013). Jatrorrhizine Hydrochloride Inhibits the Proliferation and Neovascularization of C8161 Metastatic Melanoma Cells. Anticancer Drugs 24 (7), 667-676. doi:10.1097/ CAD.0b013e328361ab28

Liu, J., Li, Q., Wang, C., Shao, J., Wang, T., Wu, D., et al. (2020). Antifungal Evaluation of Traditional Herbal Monomers and Their Potential for Inducing Cell wall Remodeling in Candida Albicans and Candida Auris. Biofouling 36 (3), 319-331. doi:10.1080/08927014.2020.1759559

Lo, S. N., Wang, C. W., Chen, Y. S., Huang, C. C., Wu, T. S., Li, L. A., et al. (2017). Berberine Activates Aryl Hydrocarbon Receptor but Suppresses CYP1A1 Induction through miR-21-3p Stimulation in MCF-7 Breast Cancer Cells. Molecules 22 (11), 1847. doi:10.3390/molecules22111847

Lou, Z. C., Gao, C. Y., Lin, F. T., Lin, M. C., Zhang, J., Jr, Slatkin, D. J., et al. (1987). Quaternary Alkaloids of Thalictrum Glandulosissimum. Planta Med. 53 (11), 498-499. doi:10.1055/s-2006-962784

Lu, K., Wei, W., Hu, J., Wen, D., Ma, B., Liu, W., et al. (2020). Apoptosis Activation in Thyroid Cancer Cells by Jatrorrhizine-Platinum(II) Complex via Downregulation of PI3K/AKT/Mammalian Target of Rapamycin (mTOR) Pathway. Med. Sci. Monit. 26, e922518-1-e922518-10. doi:10.12659/ MSM.922518
Luo, T., Zhang, H., Zhang, W. W., Huang, J. T., Song, E. L., Chen, S. G., et al. (2011). Neuroprotective Effect of Jatrorrhizine on Hydrogen Peroxide-Induced Cell Injury and its Potential Mechanisms in PC12 Cells. Neurosci. Lett. 498 (3), 227-231. doi:10.1016/j.neulet.2011.05.017

Luo, J., Yan, D., Yang, M., Dong, X., and Xiao, X. (2013). Multicomponent Therapeutics of Berberine Alkaloids. Evid. Based Complement. Alternat Med. 2013, 545898. doi:10.1155/2013/545898

Luo, S., Guo, L., Sheng, C., Zhao, Y., Chen, L., Li, C., et al. (2020). Rapid Identification and Isolation of Neuraminidase Inhibitors from Mockstrawberry (Duchesnea Indica Andr.) Based on Ligand Fishing Combined with HR-ESI-Q-TOF-MS. Acta Pharm. Sin. B 10 (10), 1846-1855. doi:10.1016/j.apsb.2020.04.001

Lyu, Y., Lin, L., Xie, Y., Li, D., Xiao, M., Zhang, Y., et al. (2021). Blood-GlucoseLowering Effect of Coptidis Rhizoma Extracts from Different Origins via Gut Microbiota Modulation in Db/db Mice. Front. Pharmacol. 12, 684358. doi:10.3389/fphar.2021.684358

Ma, H., Hu, Y., Zou, Z., Feng, M., Ye, X., and Li, X. (2016). Antihyperglycemia and Antihyperlipidemia Effect of Protoberberine Alkaloids from Rhizoma Coptidis in HepG2 Cell and Diabetic KK-Ay Mice. Drug Dev. Res. 77 (4), 163-170. doi:10.1002/ddr.21302

Malebo, H. M., Wenzler, T., Cal, M., Swaleh, S. M., Omolo, M. O., Hassanali, A., et al. (2013). Anti-Protozoal Activity of Aporphine and Protoberberine Alkaloids from Annickia Kummeriae (Engl. \& Diels) Setten \& Maas (Annonaceae). BMC Complement. Altern. Med. 13 (1), 48-10. doi:10.1186/ 1472-6882-13-48

Mao, Z., Di, X., Zhang, J., Wang, X., Liu, Y., and Di, X. (2017). Rapid and Cost-Effective Method for the Simultaneous Quantification of Seven Alkaloids in Corydalis Decumbens by Microwave-Assisted Extraction and Capillary Electrophoresis. J. Sep. Sci. 40 (14), 3008-3014. doi:10.1002/jssc.201700051

Meng, F. C., Wu, Z. F., Yin, Z. Q., Lin, L. G., Wang, R., and Zhang, Q. W. (2018). Coptidis Rhizoma and its Main Bioactive Components: Recent Advances in Chemical Investigation, Quality Evaluation and Pharmacological Activity. Chin. Med. 13 (1), 13-18. doi:10.1186/s13020-018-0171-3

Mori-Quiroz, L. M., Hedrick, S. L., De Los Santos, A. R., and Clift, M. D. (2018). A Unified Strategy for the Syntheses of the Isoquinolinium Alkaloids Berberine, Coptisine, and Jatrorrhizine. Org. Lett. 20 (14), 4281-4284. doi:10.1021/ acs.orglett.8b01702

Namthabad, S., and Mamidala, E. (2014). Molecular Docking of HIV-1 Protease Using Alkaloids from Tinospora Cordifolia. Int. J. Res. Appl. 1 (1), 12-16.

Neef, C., Oosting, R., and Meijer, D. K. (1984). Structure-Pharmacokinetics Relationship of Quaternary Ammonium Compounds. Elimination and Distribution Characteristics. Naunyn Schmiedebergs Arch. Pharmacol. 328 (2), 103-110. doi:10.1007/BF00512058

Nishiyama, Y., Moriyasu, M., Ichimaru, M., Iwasa, K., Kato, A., Mathenge, S. G., et al. (2004). Quaternary Isoquinoline Alkaloids from Xylopia Parviflora. Phytochemistry 65 (7), 939-944. doi:10.1016/ j.phytochem.2003.12.010

Odoh, U. E., Uzor, P. F., Eze, C. L., Akunne, T. C., Onyegbulam, C. M., and Osadebe, P. O. (2018). Medicinal Plants Used by the People of Nsukka Local Government Area, South-Eastern Nigeria for the Treatment of Malaria: An Ethnobotanical Survey. J. Ethnopharmacol. 218, 1-15. doi:10.1016/ j.jep.2018.02.034

Olivier, D. K., Van Vuuren, S. F., and Moteetee, A. N. (2015). Annickia Affinis and A. Chlorantha (Enantia Chlorantha)--A Review of Two Closely Related Medicinal Plants from Tropical Africa. J. Ethnopharmacol. 176, 438-462. doi:10.1016/j.jep.2015.10.021

Patel, M. B., and Mishra, S. (2011). Hypoglycemic Activity of Alkaloidal Fraction of Tinospora Cordifolia. Phytomedicine 18 (12), 1045-1052. doi:10.1016/ j.phymed.2011.05.006

Patel, M. B., and Mishra, S. (2012a). Isoquinoline Alkaloids from Tinospora Cordifolia Inhibit Rat Lens Aldose Reductase. Phytother. Res. 26 (9), 1342-1347. doi:10.1002/ptr.3721

Patel, M. B., and Mishra, S. M. (2012b). Magnoflorine from Tinospora Cordifolia Stem Inhibits $\alpha$-glucosidase and Is Antiglycemic in Rats. J. Funct. Foods 4 (1), 79-86. doi:10.1016/j.jff.2011.08.002

Pérez, E. G., and Cassels, B. K. (2010). Alkaloids from the Genus Duguetia. Alkaloids: Chem. Biol. 68, 83-156. doi:10.1016/s1099-4831(10)06803-3 
Peng, C. Y., Liu, J. Q., Zhang, R., and Shu, J. C. (2014). A New Alkaloid from the Fruit of Nandina Domestica Thunb. Nat. Prod. Res. 28 (15), 1159-1164. doi:10.1080/14786419.2014.921166

M, P., Reddy, G. J., Hema, K., Dodoala, S., and Koganti, B. (2021). Unravelling High-Affinity Binding Compounds towards Transmembrane Protease Serine 2 Enzyme in Treating SARS-CoV-2 Infection Using Molecular Modelling and Docking Studies. Eur. J. Pharmacol. 890, 173688. doi:10.1016/ j.ejphar.2020.173688

Porras, G., Chassagne, F., Lyles, J. T., Marquez, L., Dettweiler, M., Salam, A. M., et al. (2020). Ethnobotany and the Role of Plant Natural Products in Antibiotic Drug Discovery. Chem. Rev. 121 (6), 3495-3560. doi:10.1021/ acs.chemrev.0c00922

Pyne, M. E., Kevvai, K., Grewal, P. S., Narcross, L., Choi, B., Bourgeois, L., et al. (2020). A Yeast Platform for High-Level Synthesis of Tetrahydroisoquinoline Alkaloids. Nat. Commun. 11 (1), 3337. doi:10.1038/s41467-020-17172-x

Qin, R., and Jiang, H. (2011). Determination the Content of Jatrorrhizine in Thalictrum of Changbai Mountain by the Method of Thin-Layer Chromatography. North. Hortic. 14, 175-176.

Qin, Q. P., Wang, Z. F., Huang, X. L., Tan, M. X., Luo, Z. H., Wang, S. L., et al. (2019a). Two Telomerase-Targeting Pt(ii) Complexes of Jatrorrhizine and Berberine Derivatives Induce Apoptosis in Human Bladder Tumor Cells. Dalton Trans. 48 (40), 15247-15254. doi:10.1039/c9dt02381j

Qin, Q. P., Zou, B. Q., Wang, Z. F., Huang, X. L., Zhang, Y., Tan, M. X., et al. (2019b). High In vitro and In vivo Antitumor Activities of Luminecent Platinum(II) Complexes with Jatrorrhizine Derivatives. Eur. J. Med. Chem. 183, 111727. doi:10.1016/j.ejmech.2019.111727

Qiu, H., Sun, S., Ma, X., Cui, C., Chen, G., Liu, Z., et al. (2018). Jatrorrhizine Hydrochloride Suppresses Proliferation, Migration, and Secretion of Synoviocytes In Vitro and Ameliorates Rat Models of Rheumatoid Arthritis In Vivo. Int. J. Mol. Sci. 19 (5), 1514. doi:10.3390/ijms19051514

Rao, G. X., Zhang, S., Wang, H. M., Li, Z. M., Gao, S., and Xu, G. L. (2009). Antifungal Alkaloids from the Fresh rattan Stem of Fibraurea Recisa Pierre. J. Ethnopharmacol. 123 (1), 1-5. doi:10.1016/j.jep.2009.02.046

Röhrig, U. F., Reynaud, A., Majjigapu, S. R., Vogel, P., Pojer, F., and Zoete, V. (2019). Inhibition Mechanisms of Indoleamine 2,3-Dioxygenase 1 (Ido1). J. Med. Chem. 62 (19), 8784-8795. doi:10.1021/acs.jmedchem.9b00942

Romanowski, S., and Eustáquio, A. S. (2020). Synthetic Biology for Natural Product Drug Production and Engineering. Curr. Opin. Chem. Biol. 58, 137-145. doi:10.1016/j.cbpa.2020.09.006

Rosell, R., and Karachaliou, N. (2015). Relationship between Gene Mutation and Lung Cancer Metastasis. Cancer Metastasis Rev. 34 (2), 243-248. doi:10.1007/ s10555-015-9557-1

Roy, P. S., and Saikia, B. J. (2016). Cancer and Cure: A Critical Analysis. Indian J. Cancer 53 (3), 441-442. doi:10.4103/0019-509X.200658

Ryuk, J. A., Zheng, M. S., Lee, M. Y., Seo, C. S., Li, Y., Lee, S. H., et al. (2012). Discrimination of Phellodendron Amurense and P. Chinense Based on DNA Analysis and the Simultaneous Analysis of Alkaloids. Arch. Pharm. Res. 35 (6), 1045-1054. doi:10.1007/s12272-012-0612-y

Sharma, P., Mehta, M., Dhanjal, D. S., Kaur, S., Gupta, G., Singh, H., et al. (2019). Emerging Trends in the Novel Drug Delivery Approaches for the Treatment of Lung Cancer. Chem. Biol. Interact 309, 108720. doi:10.1016/j.cbi.2019.06.033

Sharma, N., Kumar, V., Chopra, M. P., Sourirajan, A., Dev, K., and El-Shazly, M. (2020). Thalictrum Foliolosum: A Lesser Unexplored Medicinal Herb from the Himalayan Region as a Source of Valuable Benzyl Isoquinoline Alkaloids. J. Ethnopharmacol. 255, 112736. doi:10.1016/j.jep.2020.112736

Shi, R., Zhou, H., Ma, B., Ma, Y., Wu, D., Wang, X., et al. (2012). Pharmacokinetics and Metabolism of Jatrorrhizine, a Gastric Prokinetic Drug Candidate. Biopharm. Drug Dispos. 33 (3), 135-145. doi:10.1002/bdd.1779

Singh, S., Verma, M., Malhotra, M., Prakash, S., and Singh, T. D. (2016). Cytotoxicity of Alkaloids Isolated from Argemone Mexicana on SW480 Human colon Cancer Cell Line. Pharm. Biol. 54 (4), 740-745. doi:10.3109/ 13880209.2015.1073334

Singh, A., Bajpai, V., Kumar, S., Singh Rawat, A. K., and Kumar, B. (2017). Analysis of Isoquinoline Alkaloids from Mahonia Leschenaultia and Mahonia Napaulensis Roots Using UHPLC-Orbitrap-MSn and UHPLC-QqQLIT-MS/ MS. J. Pharm. Anal. 7 (2), 77-86. doi:10.1016/j.jpha.2016.10.002

Slavík, J., and Slavíková, L. (1989). Alkaloids from Corydalis Nobilis (L.) Pers. And C. intermedia (L.) Mérat. Collect. Czech. Chem. Commun. 54 (7), 2009-2020.
Slobodníková, L., KoSt'álová, D., Labudová, D., Kotulová, D., and Kettmann, V. (2004). Antimicrobial Activity of Mahonia Aquifolium Crude Extract and its Major Isolated Alkaloids. Phytother. Res. 18 (8), 674-676. doi:10.1002/ptr.1517

Su, C. R., Ueng, Y. F., Dung, N. X., Vijaya Bhaskar Reddy, M., and Wu, T. S. (2007). Cytochrome P3A4 Inhibitors and Other Constituents of Fibraurea Tinctoria. J. Nat. Prod. 70 (12), 1930-1933. doi:10.1021/np0704248

Su, H., Zhang, C., Zou, X., Lu, F., Zeng, Y., Guan, H., et al. (2020). Jiao-tai-wan Inhibits Inflammation of the Gut-Brain-Axis and Attenuates Cognitive Impairment in Insomnic Rats. J. Ethnopharmacol 250, 112478. doi:10.1016/ j.jep. 2019.112478

Sun, L., Ding, F., You, G., Liu, H., Wang, M., Ren, X., et al. (2018). Development and Validation of an Uplc-Ms/ms Method for Pharmacokinetic Comparison of Five Alkaloids from Jinqi Jiangtang Tablets and its Monarch Drug Coptidis Rhizoma. Pharmaceutics 10 (1), 4. doi:10.3390/pharmaceutics10010004

Sun, Y., Gao, X., Wu, P., Wink, M., Li, J., Dian, L., et al. (2019). Jatrorrhizine Inhibits Mammary Carcinoma Cells by Targeting TNIK Mediated Wnt/ $\beta$-Catenin Signalling and Epithelial-Mesenchymal Transition (EMT). Phytomedicine 63, 153015. doi:10.1016/j.phymed.2019.153015

Tian, Y., Zhang, C., and Guo, M. (2017). Comparative Study on Alkaloids and Their Anti-Proliferative Activities from Three Zanthoxylum Species. BMC Complement. Altern. Med. 17 (1), 460. doi:10.1186/s12906-017-1966-y

Tiwari, S., Atluri, V., Kaushik, A., Yndart, A., and Nair, M. (2019). Alzheimer's Disease: Pathogenesis, Diagnostics, and Therapeutics. Int. J. Nanomedicine 14, 5541-5554. doi:10.2147/IJN.S200490

Tseng, C., Sun, M., Kao, T., Li, T., and Lin, C. (2021). Role of Coptis Chinensis in Antibiotic Susceptibility of Carbapenem-Resistant Klebsiella pneumoniae. J. Microbiol. Immunol. Infect. 7, 1-10. doi:10.1016/j.jmii.2021.07.003

Vogt, N. M., Kerby, R. L., Dill-McFarland, K. A., Harding, S. J., Merluzzi, A. P., Johnson, S. C., et al. (2017). Gut Microbiome Alterations in Alzheimer's Disease. Sci. Rep. 7 (1), 13537. doi:10.1038/s41598-017-13601-y

Wang, S., Li, X., Niu, Y., Liu, Y., Zhu, Y., Lu, X., et al. (2016). Identification and Screening of Chemical Constituents with Hepatoprotective Effects from Three Traditional Chinese Medicines for Treating Jaundice. J. Sep. Sci. 39 (19), 3690-3699. doi:10.1002/jssc.201600437

Wang, Y., Zhang, H., and Zhang, X. (2017). Effects of Jatrorrhizine on Akt/AMPK/ eNOS Signaling Pathways in Blood Vessel of Diabetes Rats. Her. Med. 36 (10), $1107-1111$.

Wang, P., Gao, X. Y., Yang, S. Q., Sun, Z. X., Dian, L. L., Qasim, M., et al. (2019a). Jatrorrhizine Inhibits Colorectal Carcinoma Proliferation and Metastasis through Wnt/ $\beta$-Catenin Signaling Pathway and Epithelial-Mesenchymal Transition. Drug Des. Devel Ther. 13, 2235-2247. doi:10.2147/DDDT.S207315

Wang, S., Jiang, W., Ouyang, T., Shen, X. Y., Wang, F., Qu, Y. H., et al. (2019b). Jatrorrhizine Balances the Gut Microbiota and Reverses Learning and Memory Deficits in APP/PS1 Transgenic Mice. Sci. Rep. 9 (1), 19575. doi:10.1038/ s41598-019-56149-9

Wen, L. N., and Xie, M. X. (2017). Spectroscopic Investigation of the Interaction between G-Quadruplex of KRAS Promoter Sequence and Three Isoquinoline Alkaloids. Spectrochim Acta A. Mol. Biomol. Spectrosc. 171, 287-296. doi:10.1016/j.saa.2016.08.013

Wu, H., He, K., Wang, Y., Xue, D., Ning, N., Zou, Z., et al. (2014). The Antihypercholesterolemic Effect of Jatrorrhizine Isolated from Rhizoma Coptidis. Phytomedicine 21 (11), 1373-1381. doi:10.1016/ j.phymed.2014.05.002

Wu, G., Mu, T., Zhang, L., and Chen, X. (2020). Jatrorrhizine Hydrochloride Alleviates Tert-Butyl Hydroperoxide-Induced Endothelial Cell Injury through its Anti-inflammatory Activity and PPAR- $\gamma$ Activation. Cel Mol Biol (Noisy-legrand) 66 (2), 125-129. doi:10.14715/cmb/2020.66.2.20

Xiang, Q., Hashi, Y., and Chen, Z. (2016). Simultaneous Detection of Eight Active Components in Radix Tinosporae by Ultra High Performance Liquid Chromatography Coupled with Electrospray Tandem Mass Spectrometry. J. Sep. Sci. 39 (11), 2036-2042. doi:10.1002/jssc.201600042

Xiao, H. T., Peng, J., Liang, Y., Yang, J., Bai, X., Hao, X. Y., et al. (2011). Acetylcholinesterase Inhibitors from Corydalis Yanhusuo. Nat. Prod. Res. 25 (15), 1418-1422. doi:10.1080/14786410802496911

Yan, R., Wang, Y., Liu, Y., and Di, X. (2012). Comparative Pharmacokinetics of Berberine, Palmatine and Jatrorrhizine in Rat Plasma after Oral Administration of Rhizoma Coptidis and Zuojinwan Using Liquid Chromatography-Tandem Mass Spectrometry. Iran. J. Pharm. Res. 11 (3), 949-957. 
Yang, W., She, L., Yu, K., Yan, S., Zhang, X., Tian, X., et al. (2016). Jatrorrhizine Hydrochloride Attenuates Hyperlipidemia in a High-Fat Diet-Induced Obesity Mouse Model. Mol. Med. Rep. 14 (4), 3277-3284. doi:10.3892/mmr.2016.5634

Yang, Y.-F., Yu, B., Zhang, X.-X., and Zhu, Y.-H. (2021). Identification of TNIK as a Novel Potential Drug Target in Thyroid Cancer Based on Protein Druggability Prediction. Medicine 100 (16), e25541. doi:10.1097/md.0000000000025541

Yu, C. J., Zheng, M. F., Kuang, C. X., Huang, W. D., and Yang, Q. (2010). Orengedoku-to and its Constituents with Therapeutic Potential in Alzheimer's Disease Inhibit Indoleamine 2, 3-dioxygenase Activity In Vitro. J. Alzheimers Dis. 22 (1), 257-266. doi:10.3233/JAD-2010-100684

Yu, H., Wang, Y., Wang, X., Guo, J., Wang, H., Zhang, H., et al. (2019). Jatrorrhizine Suppresses the Antimicrobial Resistance of Methicillin-Resistant Staphylococcus A. Exp. Ther. Med. 18 (5), 3715-3722. doi:10.3892/etm.2019.8034

Yuan, S., Fang, J., Tu Qing, M., Tu, Z., Nie, G., and Chen, L. (2010). Chemical Constituents and Antimicrobial Effect of Tinospora Sagittata (oliv.) Gagnep. Chin. Pharm. J. 10, 48-52.

Yuan, J., Zhou, J., Hu, Z., Ji, G., Xie, J., and Wu, D. (2011). The Effects of Jatrorrhizine on Contractile Responses of Rat Ileum. Eur. J. Pharmacol. 663 (13), 74-79. doi:10.1016/j.ejphar.2011.05.002

Zhang, L.-B., and Rao, G.-X. (2009). Aporphine, Protoberberine and Morphine Alkaloids from the Tubers of Stephania Yunnanensis. Biochem. Syst. Ecol. 37 (5), 622-625. doi:10.1016/j.bse.2009.08.005

Zhang, Y., Shi, Q., Shi, P., Zhang, W., and Cheng, Y. (2006). Characterization of Isoquinoline Alkaloids, Diterpenoids and Steroids in the Chinese Herb JinGuo-Lan (Tinospora Sagittata and Tinospora Capillipes) by High-Performance Liquid Chromatography/electrospray Ionization with Multistage Mass Spectrometry. Rapid Commun. Mass. Spectrom. 20 (15), 2328-2342. doi: $10.1002 / \mathrm{rcm} .2593$

Zhang, Y., Wu, W., Han, F., and Chen, Y. (2008). LC/MS/MS for Identification of In Vivo and In Vitro Metabolites of Jatrorrhizine. Biomed. Chromatogr. 22 (12), 1360-1367. doi:10.1002/bmc.1066

Zhang, B., Cao, A., Zhou, J., Hu, Z., and Wu, D. (2012). Effect of Jatrorrhizine on Delayed Gastrointestinal Transit in Rat Postoperative Ileus. J. Pharm. Pharmacol. 64 (3), 413-419. doi:10.1111/j.2042-7158.2011.01407.x

Zhang, S., Liu, X., and Yang, Q. (2017). The Study of Indoleamine 2, 3-dioxygenase 1 and its Inhibitors. Fudan Univ. J. Med. Sci. 44 (1), 1-7.

Zhang, X.-j., Chen, J.-h., Luo, L., He, W., Liu, G.-h., Gong, J., et al. (2018). Comparative Brain Pharmacokinetic Study of Jiaotai Pills in Normal and Insomnic Rats Using Brain Microdialysis Combinated with LC-MS/MS. Chin. Herbal Medicines 10 (2), 206-214. doi:10.1016/j.chmed.2018.03.006

Zhang, Y., Wang, Q., Liu, R., Zhou, H., Crommen, J., Moaddel, R., et al. (2019). Rapid Screening and Identification of Monoamine Oxidase-A Inhibitors from
Corydalis Rhizome Using Enzyme-Immobilized Magnetic Beads Based Method. J. Chromatogr. A. 1592, 1-8. doi:10.1016/j.chroma.2019.01.062

Zhao, H., Zhou, S., Zhang, M., Feng, J., Wang, S., Wang, D., et al. (2016). An In Vitro AChE Inhibition Assay Combined with UF-HPLC-ESI-Q-TOF/MS Approach for Screening and Characterizing of AChE Inhibitors from Roots of Coptis Chinensis Franch. J. Pharm. Biomed. Anal. 120, 235-240. doi:10.1016/ j.jpba.2015.12.025

Zhao, X., Wang, Y., Zheng, L., Sun, C., Wang, C., Cong, H., et al. (2018). Comparative Pharmacokinetics Study of Five Alkaloids in Rat Plasma and Related Compound-Herb Interactions Mechanism after Oral Administration of Shuanghua Baihe Tablets. Nat. Prod. Res. 32 (17), 2031-2036. doi:10.1080/ 14786419.2017.1365075

Zhou, H., Shi, R., Ma, B., Ma, Y., Wang, C., Wu, D., et al. (2013). CYP450 1A2 and Multiple UGT1A Isoforms Are Responsible for Jatrorrhizine Metabolism in Human Liver Microsomes. Biopharm. Drug Dispos. 34 (3), 176-185. doi:10.1002/bdd.1835

Zhou, Y., Cao, S., Wang, Y., Xu, P., Yan, J., Bin, W., et al. (2014). Berberine Metabolites Could Induce Low Density Lipoprotein Receptor UpRegulation to Exert Lipid-Lowering Effects in Human Hepatoma Cells. Fitoterapia 92, 230-237. doi:10.1016/j.fitote.2013.11.010

Zhu, S. L., Lei, T., Gao, X., and Tu, J. (2018). Jatrorrhizine Regulates GLUTs with Multiple Manners for Hypoglycemic Effect in Insulin-Resistance 3T3-L1 Adipocytes. Zhongguo Zhong Yao Za Zhi 43 (6), 1215-1220. doi:10.19540/ j.cnki.cjcmm.20180104.005

Conflict of Interest: The authors declare that the research was conducted in the absence of any commercial or financial relationships that could be construed as a potential conflict of interest.

Publisher's Note: All claims expressed in this article are solely those of the authors and do not necessarily represent those of their affiliated organizations, or those of the publisher, the editors, and the reviewers. Any product that may be evaluated in this article, or claim that may be made by its manufacturer, is not guaranteed or endorsed by the publisher.

Copyright (C) 2022 Zhong, Chen, Chen, Liao, Li and Ma. This is an open-access article distributed under the terms of the Creative Commons Attribution License (CC BY). The use, distribution or reproduction in other forums is permitted, provided the original author(s) and the copyright owner(s) are credited and that the original publication in this journal is cited, in accordance with accepted academic practice. No use, distribution or reproduction is permitted which does not comply with these terms. 